\title{
Role of Myeloid Cells in Oncolytic Reovirus-Based Cancer Therapy
}

\author{
Vishnupriyan Kumar ${ }^{1,+}\left(\mathbb{D}\right.$, Michael A. Giacomantonio ${ }^{1,+}(\mathbb{D})$ and Shashi Gujar $1,2,3,4, *$ \\ 1 Department of Pathology, Dalhousie University, Halifax, NS B3H 4R2, Canada; \\ vishnu.priyan@dal.ca (V.K.); M.Giacomantonio@dal.ca (M.A.G.) \\ 2 Department of Microbiology and Immunology, Dalhousie University, Halifax, NS B3H 4R2, Canada \\ 3 Department of Biology, Dalhousie University, Halifax, NS B3H 4R2, Canada \\ 4 Beatrice Hunter Cancer Research Institute, Halifax, NS B3H 4R2, Canada \\ * Correspondence: shashi.gujar@dal.ca; Tel.: +1-902-494-1973 \\ + These authors contributed equally to this work.
}

Citation: Kumar, V.; Giacomantonio, M.A.; Gujar, S. Role of Myeloid Cells in Oncolytic Reovirus-Based Cancer Therapy. Viruses 2021, 13, 654. https://doi.org/10.3390/v13040654

Academic Editors: Pranav Danthi and Maya Shmulevitz

Received: 7 March 2021

Accepted: 8 April 2021

Published: 10 April 2021

Publisher's Note: MDPI stays neutral with regard to jurisdictional claims in published maps and institutional affiliations.

Copyright: () 2021 by the authors. Licensee MDPI, Basel, Switzerland. This article is an open access article distributed under the terms and conditions of the Creative Commons Attribution (CC BY) license (https:// creativecommons.org/licenses/by/ $4.0 /)$.

\begin{abstract}
Oncolytic reovirus preferentially targets and kills cancer cells via the process of oncolysis, and additionally drives clinically favorable antitumor $\mathrm{T}$ cell responses that form protective immunological memory against cancer relapse. This two-prong attack by reovirus on cancers constitutes the foundation of its use as an anticancer oncolytic agent. Unfortunately, the efficacy of these reovirusdriven antitumor effects is influenced by the highly suppressive tumor microenvironment (TME). In particular, the myeloid cell populations (e.g., myeloid-derived suppressive cells and tumor-associated macrophages) of highly immunosuppressive capacities within the TME not only affect oncolysis but also actively impair the functioning of reovirus-driven antitumor T cell immunity. Thus, myeloid cells within the TME play a critical role during the virotherapy, which, if properly understood, can identify novel therapeutic combination strategies potentiating the therapeutic efficacy of reovirus-based cancer therapy.
\end{abstract}

Keywords: reovirus; oncolytic virus; myeloid cell plasticity; tumor-associated macrophages; myeloidderived suppressor cells; tumor microenvironment; immune checkpoint blockade; combination therapy

\section{Introduction}

Cancers arise from genetically mutated cells that proliferate uncontrollably to form tumor masses, can infiltrate surrounding tissues, and also colonize distant niches via metastatic processes [1]. These oncogenic processes often facilitate the development of a highly suppressive tumor microenvironment (TME) that consists of resident and infiltrating cells, cytokines and chemokines, and an extracellular matrix (ECM) that surrounds the tumor [2]. The immune constituents of the TME contain a high degree of inter- and intratumoral heterogeneity and often support tumor growth, progression, and metastasis [2]. Indeed, a diverse array of immune evasion strategies aiding tumor survival are the hallmark of TME.

The extensive heterogeneity of the TME and the resultant immunosuppression has been a major hurdle to the development of effective cancer treatments. Immune cells within the TME belong to both innate (e.g., myeloid cells, macrophages, dendritic cells, neutrophils, NK cells) and adaptive (e.g., T cells, B cells) arms of the immune system, and their infiltration into the tumor is highly dependent on the soluble factors present in the TME [2]. Based on the presence of these immune cells within the TME, tumors with little to no presence of immune cells are referred to as "cold" tumors, whereas "hot" tumors have an active presence of immune cells and are more likely to respond to immunotherapeutic approaches including adjuvant therapies and immune checkpoint blockade (ICB) [3] (Figure 1). Accordingly, therapeutic approaches that target both the 
cancer cells and the detrimental components of the TME have become expansive areas of research that have shown significant anticancer therapeutic potential. One such approach involves the use of oncolytic viruses (OVs) to simultaneously kill cancer cells and overturn tumor-associated immunosuppression [3-5].

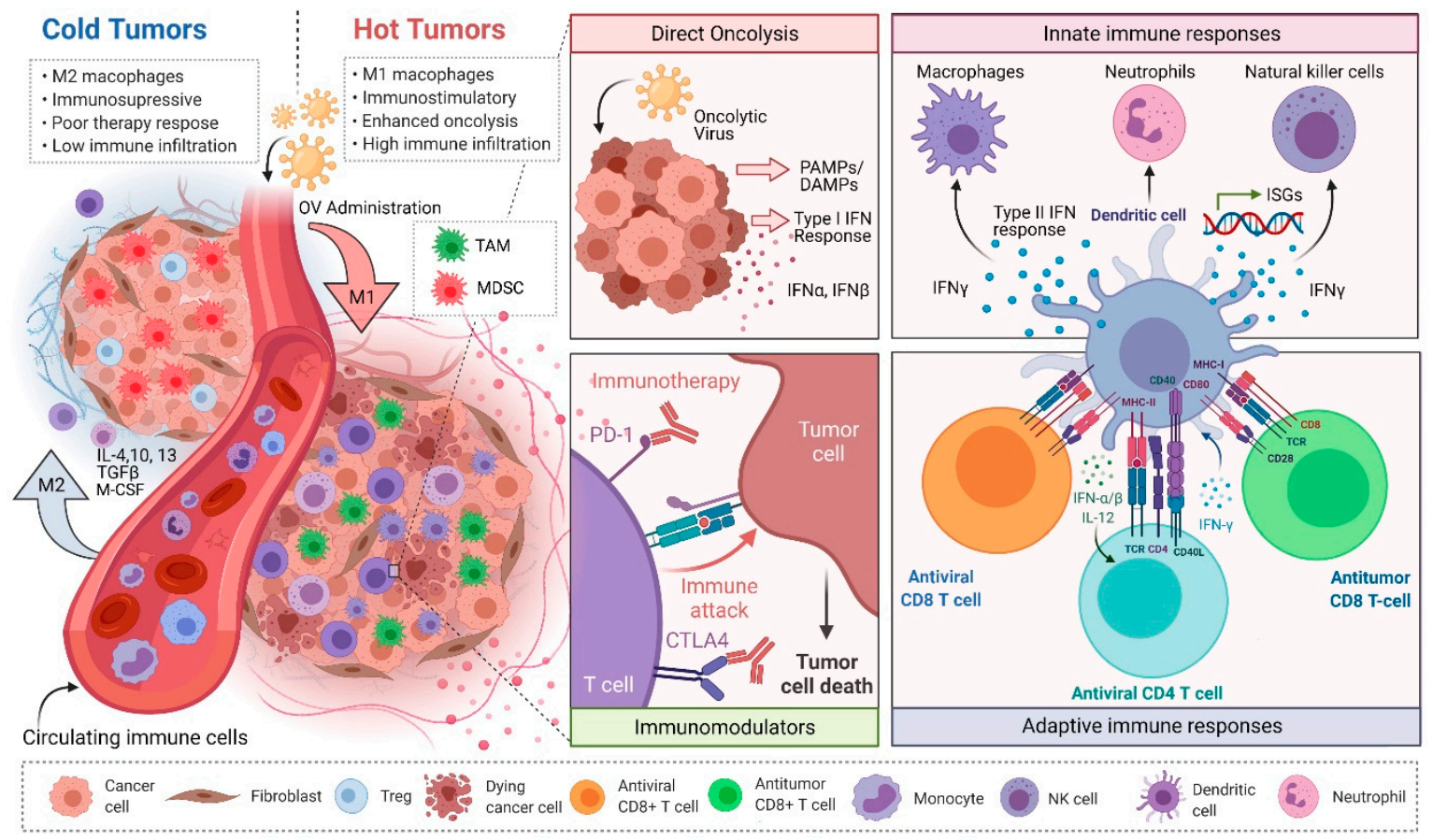

Figure 1. Overturning the tumor microenvironment (TME)-mediated immunosuppression using oncolytic virus (OV) immunotherapy. Administration of OVs can turn "cold" tumors "hot", release otherwise inaccessible tumor antigens to be processed by antigen-presenting cells (APCs) via oncolysis and also drive the activation of innate immune cells. Further, OVs alone or in combination with ICB therapy can repolarize immunosuppressive immune cells, such as TAMs and MDSCs, to antitumor phenotype and support the development of antitumor immunity. Abbreviations: OV: Oncolytic virus; PD-1: Programmed cell death protein 1; CTLA-4: Cytotoxic T-lymphocyte-associated protein 4; IFN: Interferon; ISG: Interferon stimulating genes; IL: Interleukin; PAMPs: Pathogen-associated molecular patterns; DAMPs: Damage-associated molecular patterns; TGF $\beta$ : Transforming growth factor beta; CSF: Colony-stimulating factor.

OVs are derived from naturally occurring or genetically modified viruses, and preferentially infect and lyse cancer cells through a process of oncolysis [6]. It is now clear that most cancers harbor one or more intrinsic mechanisms (e.g., defective antiviral interferon response) through which the immune evasion is facilitated [7]. Interestingly, such immune defects within cancer cells also make them preferentially susceptible to infection by OVs. Additionally, multiple immunosuppressive strategies within the TME provide additional support towards the replication of OVs. Thus, as compared to non-transformed or "normal" cells, cancer cells and the TME represent a preferential niche enabling OV oncolysis [8].

Currently, many viruses are being investigated as OVs in preclinical and clinical testing, including reovirus [9]. While mammalian orthoreovirus (herein reovirus) is the most prevalent strain used in OV research, the oncolytic capacity of other zoonotic strains, such as avian orthoreovirus, are actively being explored for their potential use in patients with pre-existing immunity to mammalian orthoreoviruses $[10,11]$. Reovirus preferentially replicates in cancer or transformed cells and kills them via direct oncolysis [12]. Additionally, reovirus also overturns numerous immune evasion mechanisms present within the TME and facilitates the activation of antitumor CD8+ T cell responses [13-16]. Similar to other OVs, oncolytic reovirus-driven CD8+ antitumor T cell responses can target cancer cells-both at local and metastatic sites. Most importantly, reovirus-driven antitumor T cell immune response can resist a tumor challenge, suggesting the ability to protect against 
possible cancer relapse, and is clinically desired [17]. Unfortunately, while these reovirusinduced antitumor T cell responses are very promising, their efficacy is stunted by the TME. More specifically, the TME orchestrates the recruitment and differentiation of suppressive immune cells such as myeloid-derived suppressor cells (MDSCs) and tumor-associated macrophages (TAMs) that actively inhibit antitumor immune activities and enable cancer cells to escape immune-mediated elimination. Considering this significant impact, here we discuss the role of MDSCs and TAMs in the context of oncolytic reovirus-induced antitumor immunity, the detailed understanding of which will aid the optimum harnessing of reovirus-based cancer therapies.

\section{Myeloid Cell Plasticity and the TME}

The innate immune system represents an intricate network of highly diverse cells that collectively function to identify and eliminate pathogens from the body. Amongst these cells are myeloid cells, from which monocytes and macrophages originate (Figure 2). Monocytes and macrophages are found in the peripheral blood and are recruited to various tissues where they differentiate into their effector phenotype depending on the stimuli encountered in their microenvironment [18]. In response to a pathogen, macrophages are the first line of defense and can drive the initiation of an adaptive immune response through phagocytosis and antigen presentation [19]. Additionally, macrophages play a significant role in dictating the immune response either by maintaining homeostasis or through the secretion of immunogenic molecules including cytokines, chemokines, and complement factors [19]. However, the differentiation and physiological function of myeloid cells is context dependent and adaptable based on the stimuli encountered in their microenvironment [20].

\subsection{M1 vs. M2 Macrophage Paradigm}

Macrophage diversity is so extensive that it has been a significant cause of controversy within the field in regard to how different populations of macrophages should be classified [21-24]. While this debate still rages within the field of macrophage biology, the majority of researchers have adopted a model where macrophages are broadly classified into two types that represent opposing ends of a polarization spectrum: Classically activated (M1) and alternatively activated (M2) (Figure 2). M1 macrophages are polarized in response to pro-inflammatory stimuli such as interferon-gamma (IFN $\gamma$ ), lipopolysaccharide (LPS), granulocyte-macrophage colony-stimulating factor (GM-CSF), and toll-like receptor (TLR) stimulation. These cells develop a phenotype with functions that include pro-inflammatory cytokine production, endothelial cell activation, antiviral defense, and immune cell recruitment. Conversely, alternatively activated (M2) macrophages differentiate in response to anti-inflammatory stimuli such as interleukin-4 (IL-4) and macrophage colony-stimulating factor (M-CSF), generating a phenotype that specializes in tissue homeostasis, phagocytosis of apoptotic cells, and the production of anti-inflammatory cytokines (e.g., IL-4, $-10,-13)[22,25,26]$. In the context of cancer, M1 macrophages have antitumor properties, whereas M2 macrophages are immunosuppressive and are tumor-promoting [27]. Unfortunately, the current suboptimal levels of therapy responses to advanced treatments such as immune checkpoint blockade can be attributed to the complex heterogeneity within in the TME [28]. This complexity further makes it challenging to identify patients who will respond better to these drugs. A recent quest carried out in 98 pan-cancer patient data in the spirit of identifying biomarkers of value reiterated the prognostic significance of M1/M2 macrophage ratio [29,30]. It is also worth mentioning that the stimuli of polarization is a net result of the dynamic spectrum of various spatiotemporal signals present at the local environment [31]. While this nomenclature reflects a highly simplified model of myeloid cell plasticity, a comprehensive review of monocyte/macrophage dichotomy lies outside of the scope of this review and has been described elsewhere [32,33]. However, an understanding of how myeloid cell polarization is regulated in the context of the TME is critical in addressing the shortcomings of OV therapies. 


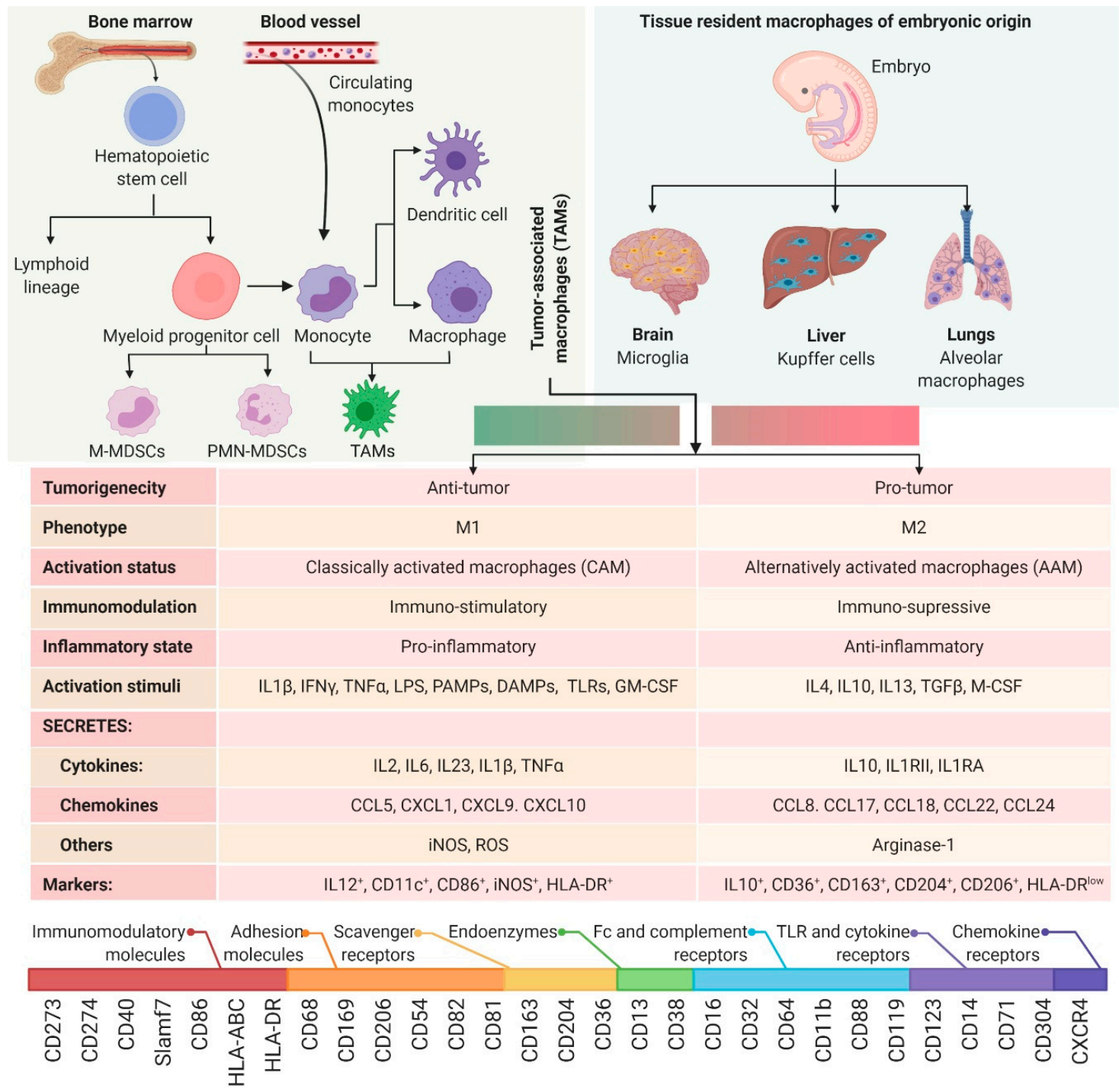

Figure 2. Ontogeny of macrophages. Top panel (left): Sources of macrophage recruitment, namely bone marrow and circulating monocytes; top panel (right): Various types of tissue resident macrophages; middle table: Characteristics of macrophage dichotomy; bottom: The spectrum of surface markers used to phenotype macrophages. Abbreviations: CAM: Classically activated macrophages; AAM: Alternatively activated macrophages; M-MDSC: Monocytic myeloid-derived suppressor cell; PMN-MDSC: Polymorphonuclear/granulocytic myeloid-derived suppressor cell; IL: Interleukin; IFN: Interferon; LPS: Lipopolysaccharide; PAMPs: Pathogen-activated molecular patterns; DAMPs: Damage-associated molecular patterns; TLR: Toll-like receptor; TNF: Tumor necrosis factor; CSF: Colony-stimulating factor; GM-CSF: Granulocyte-macrophage colony-stimulating factor; TGF: Transforming growth factor; iNOS: Nitric oxide synthase (inducible); ROS: Reactive oxygen species; CCL: Chemokine ligand; CXCL: C-X-C motif chemokine ligand; CD: Cluster of differentiation; HLA: Human leukocyte antigen; Slamf7: Signaling lymphocytic activation molecule F7.

\subsection{Myeloid-Derived Suppressor Cells (MDSCs)}

TME-associated growth factors, cytokines and chemokines mediate altered hematopoiesis that drives the generation of immunosuppressive MDSCs [34]. These chemotactic agents within TME also facilitate the migration of MDSCs. In animal models, the presence of C-C Motif Chemokine Ligand 2 (CCL2 or MCP-1), CCL3, CCL4, C-X-C ligand 12 (CXCL12), IL-6, IL-1 $\beta$, M-CSF and vascular endothelial growth factor (VEGF) in the TME promoted MDSC infiltration $[35,36]$. MDSCs can be of polymorphonuclear/granulocytic phenotype (PMN-MDSC) or the monocytic phenotype (M-MDSC) [37]. Monocytes differentiate into macrophages and dendritic cells; whereas polymorphonuclear cells give rise to neutrophils, 
eosinophils, basophils, and mast cells [38]. The proliferation and differentiation of MDSCs are regulated by similar growth factors that regulate macrophage differentiation; namely M-CSF, G-CSF and GM-CSF [39]. Interestingly, however, MDSC recruitment and differentiation is believed to be much more complex than that of macrophages since signaling pathways are required to maintain their highly immature state [39]. Apart from the growth factors mentioned above, additional MDSC signaling pathways include a combination of TLR4 and IFN $\gamma$ signaling, and the activation of the STAT3 pathway, amongst many more [40,41]. High frequencies of these cells clinically correlate with increased oncogenesis, metastasis and poor prognosis $[37,42,43]$. Moreover, the physical interaction between TAMs and MDSCs results in pro-tumorigenic Th2 immune response [44]. MDSCs also suppress antitumor $\mathrm{T}$ cell activities and promote angiogenesis [45]. Therefore, myeloid cell reprogramming strategies, alone or in combination with immunotherapies and anti-angiogenic strategies, will prove useful in combating these suppressive stimuli within the TME.

\subsection{Tumor-Associated Macrophages (TAMs)}

While often considered synonymous with M2 macrophages, TAMs can have characteristics of both M1 and M2 phenotypes depending on the type of cancer, stage of the tumor, and the TME [46]. Therefore, TAMs have a distinct phenotype from conventional macrophages, exhibiting significantly more immunosuppressive capacities than traditional M2 macrophages [46]. TAMs can originate from tissue resident macrophages or can develop from monocyte precursors in the blood [47]. The functional fate of TAMs is decided upon their recruitment into the TME in response to growth factors, cytokines and chemokines [27,48]. Signaling pathways known to drive TAM differentiation include VEGF, M-CSF, IL-4, CCL-2, -9 , and -18 [48]. TAMs have been shown to make up to $50 \%$ of a tumors mass $[49,50]$ and are therefore critical regulators of how a patient will respond to therapy [49]. In fact, TAM abundance in the TME has been shown to negatively correlate with survival in numerous cancers including breast cancer, renal cell carcinoma, glioblastoma, pancreatic cancer, head and neck cancer, lymphoma, and bladder cancer [22,31,32,51-58]. Moreover, TAMs have been shown to be instrumental for tumor relapse and metastasis in breast cancer [59-61]. Meta-analysis of clinical reports highlights that over $80 \%$ of the studies show a positive correlation between increased TAM density and poor patient prognosis [62]. CCL2 has also been reported to recruit TAMs which promotes metastasis in bone [63] and breast cancer [64] models. Interestingly, GM-CSF administration has been shown to counteract the immunosuppression and promote antitumor environment, likely by driving a more favorable pro-inflammatory TAM phenotype in addition to stimulating DC differentiation [65].

While TAMs and MDSCs are often similar in cellular functionality, they can be phenotypically distinguished from each other based on surface marker expression [48]. Additionally, while MDSCs are considered entirely tumor-promoting, TAMs have been shown to have both pro- and anti-tumor properties depending on the type of cancer, likely due to their previous roles as tissue resident macrophages prior to oncogenesis $[48,66]$. A better understanding of the intricacies involved in TME-TAM signaling will undoubtably provide more anticancer treatment options.

\section{Reovirus-Based Dual-Prong Anticancer Actions and Myeloid Cells}

Two main modes through which reovirus performs antitumor functions during virotherapy are: direct oncolysis and antitumor immunity. Following the therapeutic administration in cancer-bearing hosts, the efficacy of these reovirus-induced anticancer effects can be influenced by the myeloid cells within the TME.

\subsection{Direct Oncolysis}

While immunosuppression within the TME provides cancer cells with a competitive growth advantage, it also renders them conducive to reovirus infection and replication [67-69]. 
Here, the immunosuppressive components of the TME create an immune-privileged enclosure away from the reach of the properly functioning immune cells.

Like most viruses, productive reovirus infection is dependent on the host intracellular replication machinery [70]. The process of cellular transformation within cancer cells brings about dysregulation in metabolism and aberrant cell signaling pathways [1]. Reoviruses demonstrate an inherent propensity to infect transformed cells with such disrupted physiology [12]. The release of progeny viruses often leads to host cancer cell death, which makes it a lytic life cycle; the process is known as "oncolysis" [71]. Direct oncolysis by viral replication is facilitated using various signaling pathways involving $\operatorname{TNF} \alpha$, Fas ligand (FasL), TNF-related apoptosis-inducing ligand (TRAIL), ROS and others [72-74], and can lead to different types of cell death in different cancers $[67,75]$. Thus, reovirus-induced oncolysis of cancer cells involves multifaceted and complex interaction between cancer cells and surrounding tissues. In line with their immuno-modulatory effects, myeloid cells can influence reovirus-mediated oncolysis of cancer cells in a context-dependent manner. For example, M1 vs. M2 macrophages themselves bear different susceptibilities to virus infection and thus hold capacities to differentially regulate virus loads in the hosts [76]. Similarly, MDSCs themselves can carry replication-competent reovirus [77]. Nonetheless, the evidence on the role of myeloid cells on reovirus-mediated direct oncolysis, despite being important, is still in its infancy, and must be pursued further. These studies also should provide consideration for myeloid cell heterogeneity as the lack of information on the precise myeloid cell phenotypes has generated rather conflicting information for the OV field. For instance, while enhanced replication and oncolysis has been attributed to increased macrophage presence in oncolytic herpes simplex virus (HSV) infection of glioma, the depletion of macrophages in HSV-treated glioma was shown to result in higher titers of OV [78]. Similarly, in mesothelioma models, the presence of MDSCs hindered the ability of oncolytic modified vaccinia Tiantan (MVTT) to perform oncolysis and ablation of MDSCs restored the oncolytic efficacy of MVTT [79]. These findings are indicative that myeloid cells are central in orchestrating the OV-mediated oncolysis, and validate the notion that targeted reprogramming of MDSCs and TAMs will serve as a viable strategy to improve OV efficacy.

\subsection{Reovirus-Induced Antitumor Immunity}

Unfortunately, while the suppressive nature of the TME is actively involved in facilitating a productive reovirus infection [80], it also represents a daunting hindrance towards the initial activation and subsequent actions of antitumor CD8+ T cells [81]. Interestingly, reovirus has been shown to overturn many different immune evasion strategies present within the TME; examples include the promotion of antigen presentation and co-stimulation by antigen-presenting cells (including macrophages), recruitment of APCs and $\mathrm{T}$ cells within TME, subsequent trafficking to the lymph nodes, and production of pro-inflammatory cytokines. Cumulatively, these reovirus-driven immunological events drive the successful activation of protective antitumor CD8+ T cell responses. Unfortunately, the therapeutic injection of reovirus also promotes the recruitment of suppressive MDSCs which dampen the functions of antitumor CD8+ T cells [82]. Indeed, the inhibition of MDSC recruitment via C-C chemokine receptor type 2 (CCR2)-dependent mechanism or gemcitabine potentiates reovirus-induced antitumor effects $[15,83]$. Further, reovirus successfully inhibits the immunosuppressive activity of MDCSs in a TLR3-dependent manner and promotes antitumor CD8+ T cell responses [84]. Thus, the TME hosts a dynamic environment which although immunosuppressive can be harnessed to drive reovirus-induced antitumor benefits [6]. It should be noted that, similar to reovirus, the therapeutic implications for myeloid cells apply to other OVs as well. For example, oncolytic adenovirus and HSV infection led to increased infiltration of immunostimulatory macrophages in glioma [85,86], and exposure to oncolytic paramyxovirus resulted in skewing of macrophage phenotype towards antitumor capacity [87]. Further, oncolytic HSV in combination with gemcitabine has shown to effectively suppress MDSCs and result 
in tumor regression and enhanced oncolysis accompanied by antitumor CD4+ and CD8+ T cell responses [88]. Going forward, the context-dependent consideration for myeloid cell heterogeneity within OV-induced antitumor immune responses will be a key factor. Therefore, combination therapeutic strategies targeting the immunosuppressive aspects of the TME with specific regards to direct oncolysis and antitumor immunity will create optimal clinical outcomes from reovirus-based cancer therapy.

\section{Targeting Myeloid Cells to Improve Reovirus Therapy}

Considering the immunosuppressive effects of the MDSCs and TAMs on antitumor immunity, currently many therapeutic strategies are being developed or tested to target these immunosuppressive myeloid cells, and thus are discussed below. It is worth mentioning that myeloid cells are merely one of many immunosuppressive cell types in the TME. For example, $\mathrm{CD}^{+}{ }^{+} \mathrm{FoxP}^{+}$regulatory $\mathrm{T}$ cells $\left(\mathrm{T}_{\text {regs }}\right)$ are highly immunosuppressive, and often play a central role in driving tumor immune evasion and suppression of antitumor immunity [89]. In fact, myeloid cells have been shown to drive the differentiation of $\mathrm{T}_{\text {regs }}$ in the TME through direct cell-cell interactions [90], further supporting the rational to therapeutically target MDSCs and TAMs during OV therapy. While a proper description of $\mathrm{T}_{\text {reg }}$ biology and function lies outside the scope of this review, this has been discussed extensively elsewhere $[89,91,92]$. Here, we discuss different combination therapy strategies aimed at targeting suppressive myeloid cells. Of note, many of the strategies are not yet used in conjunction with OVs; however, they are still discussed in anticipation of their future use in the context of OV-based cancer therapies such as reovirus.

\subsection{Blocking Recruitment}

Blocking MDSCs and TAM recruitment can be an effective strategy to hinder tumorigenesis and alleviate immunosuppression. As CCL2 recruits TAMs and MDSCs that are positive for chemokine receptor CCR2 in TME $[93,94]$, blockade of CCL2/CCR2 reverts the MDSC infiltration in in vivo models [95]. Accordingly, the ablation of CCR2 inhibition causes tumor relapse, favoring angiogenesis and metastasis in breast cancer models [96]. CCR2 inhibitors such as carlumab (CNTO 888), PF-04136309, MLN1202, BMS-813160, and CCX872-B are currently in clinical trials [97]. The CXCL-12-CXCR-4 axis also orchestrates the recruitment of TAMs via endothelial barrier into hypoxic tumor regions [98], and targeting CXCL-12-CXCR-4 axis alleviates tumor burden and metastatic susceptibility in breast, prostate, and ovarian cancer models by averting TAM infiltration [99,100]. Unfortunately, therapeutic administration of reovirus drives immediate recruitment of MDSCs in TME, which, if inhibited, potentiates antitumor CD8+ T cell responses [15].

\subsection{Depleting Macrophage Populations in the TME}

TAMs can be directly depleted by triggering apoptosis [101]. Bisphosphonates preferentially target phagocytic cells such as TAMs and elicit myeloid cell cytotoxicity [102]. Zoledronate, a third-generation bisphosphonate displays cytotoxicity towards matrix metalloproteinase-9 (MMP9)-expressing TAMs and enhances antitumor activity of macrophages by reprogramming monocyte differentiation towards a pro-inflammatory phenotype [103]. Trabectedin, a chemotherapeutic agent, selectively elicits cell death in monocytes including TAMs through the activation of the caspase- 8 cascade via TRAIL receptors [104]. Retrospective analysis of data from 34 patients who received trabectedinbased chemotherapy revealed that $56 \%$ of patients were found to have a reduction in monocytes in the tumor [104]. Trabectedin administration prior to oncolytic HSV injection has been shown to deplete intratumoral myeloid cells including macrophages [105]. Importantly, Trabectedin prevented the increase in intratumoral infiltration of these cells upon oncolytic HSV injection [105]. The depletion of TAMs also markedly increased the antitumor efficacy of oncolytic HSV by significantly altering the TME [105] in many models including Ewing Sarcoma and glioblastoma [106]. These and similar other myelolytic treatments are promising strategies to synergistically increase OV therapy efficacy. 


\subsection{Reprogramming Metabolism}

In macrophages, growth-factor-driven metabolic rewiring results in phenotypic alterations that enable them to adapt to their environment and perform their immune effector functions. For example, in response to pro-inflammatory stimuli, M1 macrophages disrupt the tricarboxylic acid (TCA) cycle at two points—after citrate and after succinate-driving fatty acid synthesis (FAS) and IL-1 $\beta$ production which are central to their pro-inflammatory phenotype [107-110]. Conversely, in the context of anti-inflammatory stimuli, M2 macrophages have an intact TCA cycle that favors mitochondrial oxidative phosphorylation (OXPHOS), resulting in a greater yield of ATP [107-110]. Accordingly, inhibition of ATP synthesis in these macrophages using ATP synthase inhibitor, oligomycin, or hexokinase inhibitor, 2-deoxyglucose suppresses anti-inflammatory gene and marker expression, and overall function $[111,112]$. Therefore, it is not surprising that TME-associated metabolic aberrations affect the functional attributes of TAMs. Thus, targeted metabolic reprogramming of macrophages in the context of metabolic perturbations within the TME represent next frontiers in harnessing OV cancer therapy efficacies.

\subsection{Reprogramming Cellular Signaling}

OVs in combination with strategies aimed to overturn the immunosuppressive cues in the TME are effective tools to reprogram myeloid cells towards an antitumor phenotype. TAMs and MDSCs can be re-educated to be tumoricidal using strategies such as, but not limited to CSF1/CSF1R blockades, TLR agonists, PI3K $\gamma$ inhibitors, CD40 agonists, and Class IIa histone deacetylase (HDAC) inhibitors [113]. The surface receptors of macrophages that facilitate antibody-dependent cellular cytotoxicity/phagocytosis (ADCC/ADCP) are attractive targets. Tumor cells express CD47 which recognize signal regulatory protein alpha $(\mathrm{SIRP} \alpha)$ receptor on macrophages to help them escape immune surveillance [114]. However, this can be overcome by employing anti-SIRP $\alpha$ antibody to elicit macrophage-dependent cellular phagocytosis [115]. TLRs are also capable of directing TAMs towards a pro-inflammatory antitumor phenotype, when subjected to TLR agonists. TLR7/TLR8 agonists have been shown to counteract subcutaneous melanoma in vivo, in concert with ICB therapy. CSF1R inhibition when combined with oncolytic adenovirus and anti-PD-1 antibody enhances tumor regression and confers survival advantage to mouse models of colon cancer [116]. An oncolytic adenovirus engineered with TLR agonistic immunostimulatory-islands can overcome myeloid cell-mediated immunosuppression and elicit effective antitumor $\mathrm{T}$ cell responses [117]. Arming an oncolytic adenovirus with CD40L successfully repolarizes M2 macrophages, induces oncolysis and promotes intratumoral T cell infiltration and expansion [118]. These arguments underline the potential of reprogramming TAMs and MDSCs for enhancing OV efficacy.

Considering the central role of GM-CSF in myeloid cell biology, OVs have been engineered to express this cytokine. Recently, Kemp et al., successfully generated reoviruses that express murine and human GM-CSF (rS1-mmGMCSF and rS1-hSGMCSF, respectively). In a murine model of pancreatic cancer, intratumoral treatment with rS1-mmGMCSF resulted in an increase in T cell activation at distant metastatic tumor sites [119]. This supports the notion that reprogramming the TME by targeting myeloid populations improves the ability of reovirus to drive an antitumor $\mathrm{T}$ cell response. With respect to other OVs, Pexa-Vec (also known as JX-594), a vaccinia virus, has been engineered to express GM-CSF in order to repolarize infiltrating MDSCs and TAMs [120]. Trials using Pexa-Vec have demonstrated safety and showed antitumor activities in colorectal, hepatocellular and pediatric cancer [121,122]. Similarly, RP1, an oncolytic herpes simplex virus (HSV) armed with GM-CSF encoding region [123], has reported increased immune infiltration and robust CD8+ T cell responses [124]. The first approved [125] OV for clinical use namely T-VEC (Talimogene laherparepvec) [126], is armed with one cassette encoding human GM-CSF [127]. A list of clinical trials which use OVs in combination with immunomodulating therapies aimed to reprogram MDSCs and TAMs in various cancers can be found in Table 1. 
Table 1. List of clinical trials using OVs in combination with immunomodulatory strategies for various cancers.

\begin{tabular}{|c|c|c|c|c|c|c|}
\hline \multirow{2}{*}{ Trial } & \multirow{2}{*}{ Virus Type } & \multirow{2}{*}{ OV Agent } & \multicolumn{2}{|c|}{ Immunomodulatory Therapy } & \multirow{2}{*}{ Phase (s) } & \multirow{2}{*}{ Cancer (s) } \\
\hline & & & Agent & Description & & \\
\hline NCT03747744 & HSV & $\mathrm{T}-\mathrm{Vec}$ & CD1c (BDCA-1)+ myDC & $\begin{array}{l}\text { CD1c+ myeloid } \\
\text { dendritic cells }\end{array}$ & I & Melanoma \\
\hline NCT02197169 & Adenovirus & DNX-2401 & IFN $\gamma$ & Pro-inflammatory & I & Glioblastoma or Gliosarcoma \\
\hline NCT02143804 & Adenovirus & CG0070 & GM-CSF (encoded) & M1 polarizer & II & $\begin{array}{l}\text { Bladder Cancer, High Grade, } \\
\text { Non-Muscle Invasive }\end{array}$ \\
\hline NCT00625456 & Vaccinia & $\begin{array}{l}\text { RACVAC } \\
\text { (JX-594) }\end{array}$ & GM-CSF (encoded) & M1 polarizer & I & $\begin{array}{l}\text { Melanoma, Lung Cancer Renal } \\
\text { Cell Carcinoma, Squamous Cell } \\
\text { Carcinoma of the Head and } \\
\text { Neck, Neuroblastoma }\end{array}$ \\
\hline NCT01169584 & Vaccinia & $\begin{array}{l}\text { RACVAC } \\
\text { (JX-594) }\end{array}$ & GM-CSF (encoded) & M1 polarizer & I & $\begin{array}{l}\text { Rhabdomyosarcoma, } \\
\text { Lymphoma Wilm's Tumor, } \\
\text { Ewing's Sarcoma }\end{array}$ \\
\hline NCT04725331 & Vaccinia & BT-001 & $\begin{array}{l}\text { Anti CTLA-4 mAb } \\
\text { (encoded) }\end{array}$ & ICB & I, II & $\begin{array}{l}\text { Solid Tumor, Adult Metastatic } \\
\text { Cancer Soft Tissue Sarcoma, } \\
\text { Merkel Cell Carcinoma, } \\
\text { Melanoma, Triple Negative } \\
\text { Breast Cancer Non-Small Cell } \\
\text { Lung Cancer }\end{array}$ \\
\hline \multirow[b]{2}{*}{ NCT04050436 } & \multirow[b]{2}{*}{ HSV } & \multirow[b]{2}{*}{ RP1 } & GM-CSF (encoded) & M1 polarizer & II & \multirow[b]{2}{*}{ Squamous Cell Carcinoma } \\
\hline & & & $\begin{array}{l}\text { Cemiplimab } \\
\text { (combination) }\end{array}$ & PD-1 & & \\
\hline \multirow[b]{2}{*}{ NCT03767348 } & \multirow[b]{2}{*}{ HSV } & \multirow[b]{2}{*}{ RP1 } & GM-CSF (encoded) & M1 polarizer & II & \multirow[b]{2}{*}{ Melanoma, NSCLC } \\
\hline & & & $\begin{array}{l}\text { Nivolumab } \\
\text { (combination) }\end{array}$ & PD-1 & II & \\
\hline NCT00554372 & Vaccinia & JX-594 & GM-CSF (encoded) & M1 polarizer & II & Hepatocellular Carcinoma \\
\hline NCT00629759 & Vaccinia & JX-594 & GM-CSF (encoded) & M1 polarizer & I & Liver neoplasms \\
\hline NCT04521764 & Measles & MV & NAP (encoded) & $\begin{array}{l}\text { Secretes neutrophil } \\
\text { activating protein }\end{array}$ & I & Breast cancer \\
\hline
\end{tabular}

\subsection{Immune Checkpoint Blockade (ICB)}

Blockade of immune checkpoint proteins namely, programmed cell death protein 1 (PD-1), its ligand PD-L1, and cytotoxic T-lymphocyte-associated protein 4 (CTLA-4) in combination with reovirus have shown potential in improving efficacy of reovirus therapy (Table 2). This therapeutic approach is not restricted to reovirus, as other OVs are also increasingly explored to function in synergy with ICB therapies. Table 3 lists the clinical trials currently underway which employ OVs in combination with ICB therapies for various cancers. Within these mainstream immune checkpoints, PD-L1 is known to be expressed on MDSCs and TAMs, and thus ICB with anti-PD-L1 strategies can directly affect myeloid cell functions [128]. While PD-1 and CTLA-4 are known to be expressed mainly on effector immune cells (e.g., $\mathrm{T}$ and NK cells), the blockade of both these molecules have shown to reprogram myeloid biology and to bear therapeutic implications $[129,130]$. Interestingly, MDSCs have also been identified to be a key mediator in conferring resistance to cancer immunotherapy [131]. While anti-PD-L1 and anti-PD-1 therapy are often discussed interchangeably, literature is beginning to show differences in patient responses. Accordingly, research has shown a differential response to PD-1 blockade and PD-L1 blockade in myeloid cells, where the latter leads to more robust inflammatory responses including IL-18 production and inflammasome activation [132]. An understanding of how these responses differ in the context of reovirus therapy is required and will lead to a better approach to combination therapy. 
Table 2. List of clinical trials using reovirus in combination with immune checkpoint blockade therapies for various cancers.

\begin{tabular}{|c|c|c|c|c|c|}
\hline \multirow{2}{*}{ Trial } & \multirow{2}{*}{ Reoviral Agent } & \multicolumn{2}{|c|}{ ICB therapy } & \multirow{2}{*}{ Phase (s) } & \multirow{2}{*}{ Cancer (s) } \\
\hline & & Agent & Target & & \\
\hline NCT03723915 & Pelareorep & Pembrolizumab & PD-1 & II & Pancreatic adenocarcinoma, Pancreatic cancer \\
\hline NCT03605719 & Pelareorep & Nivolumab & PD-1 & I & Recurrent Plasma Cell Myeloma \\
\hline NCT04102618 & Pelareorep & Atezolizumab & PD-L1 & I & Breast cancer \\
\hline NCT02620423 & Reolysin & Pembrolizumab & PD-1 & I & Pancreatic Adenocarcinoma \\
\hline NCT04445844 & Pelareorep & Retifanlimab & PD-1 & II & Breast cancers \\
\hline NCT04215146 & Pelareorep & Avelumab & PD-L1 & II & Metastatic breast cancer \\
\hline
\end{tabular}

Table 3. List of clinical trials using OVs in combination with immune checkpoint blockade therapies for various cancers.

\begin{tabular}{|c|c|c|c|c|c|c|}
\hline \multirow{2}{*}{ Trial } & \multirow{2}{*}{ Virus Type } & \multirow{2}{*}{ OV Agent } & \multicolumn{2}{|c|}{ ICB Therapy } & \multirow{2}{*}{ Phase (s) } & \multirow{2}{*}{ Cancer (s) } \\
\hline & & & Agent & Target & & \\
\hline NCT03004183 & Adenovirus & $\mathrm{ADV} / \mathrm{HSVtk}$ & Pembrolizumab & PD-1 & II & Metastatic NSCLC, Metastatic TNBC \\
\hline NCT02798406 & Adenovirus & DNX-2401 & Pembrolizumab & PD-1 & II & Glioblastoma, Gliosarcoma \\
\hline NCT03003676 & Adenovirus & ONCOS-102 & Pembrolizumab & PD-1 & I & $\begin{array}{l}\text { Advanced/unresectable melanoma progressing after } \\
\text { PD-1 blockade }\end{array}$ \\
\hline NCT03408587 & Coxsackie & CAVATAK & Ipilimumab & CTLA-4 & $\mathrm{Ib}$ & Uveal Melanoma with Liver Metastases \\
\hline NCT02565992 & Coxsackie & CAVATAK & Pembrolizumab & PD-1 & I & Advanced Melanoma \\
\hline NCT02824965 & Coxsackie & CAVATAK & Pembrolizumab & PD-1 & I, II & Advanced NSCLC \\
\hline NCT03153085 & HSV & $\begin{array}{c}\text { HF10 } \\
\text { (TBI-1401) }\end{array}$ & Ipilimumab & CTLA-4 & II & Unresectable/Metastatic Melanoma \\
\hline NCT02272855 & HSV & $\begin{array}{c}\text { HF10 } \\
\text { (TBI-1401) }\end{array}$ & Ipilimumab & CTLA-4 & II & Unresectable/Metastatic Melanoma \\
\hline NCT03259425 & HSV & $\begin{array}{l}\text { HF10 } \\
\text { (TBI-1401) }\end{array}$ & Nivolumab & PD-1 & II & Resectable Stage IIIB/C, IV Melanoma \\
\hline NCT01740297 & HSV & $\mathrm{T}-\mathrm{Vec}$ & Ipilimumab & CTLA-4 & $\mathrm{Ib}, \mathrm{II}$ & Unresected Stage IIIb/IV melanoma \\
\hline NCT02263508 & HSV & T-Vec & Pembrolizumab & PD-1 & $\mathrm{Ib}, \mathrm{III}$ & Unresectable Stage IIIb/IV Melanoma \\
\hline NCT02626000 & HSV & T-Vec & Pembrolizumab & PD-1 & $\mathrm{Ib}, \mathrm{III}$ & Recurrent/Metastatic HNSCC \\
\hline NCT02879760 & Maraba Virus & MG1-MAGEA3 & Pembrolizumab & PD-1 & I, II & Previously treated NSCLC \\
\hline \multirow{2}{*}{ NCT03206073 } & \multirow{2}{*}{ Vaccinia } & \multirow{2}{*}{ Pexa Vec } & Durvalumab & PD-L1 & \multirow{2}{*}{ I, II } & \multirow{2}{*}{ Refractory Colorectal Cancer } \\
\hline & & & Tremelimumab & CTLA-4 & & \\
\hline NCT02977156 & Vaccinia & Pexa Vec & Ipilimumab & CTLA-4 & I & Metastatic/Advanced Solid Tumors \\
\hline NCT03071094 & Vaccinia & Pexa Vec & Nivolumab & PD-1 & I, IIa & Advanced HCC \\
\hline \multirow{2}{*}{ NCT04185311 } & \multirow{2}{*}{ HSV } & \multirow{2}{*}{$\mathrm{T}-\mathrm{Vec}$} & Ipilimumab & CTLA-4 & \multirow{2}{*}{ I } & \multirow{2}{*}{ Localized Breast Cancer } \\
\hline & & & Nivolumab & PD-1 & & \\
\hline NCT03889275 & $\begin{array}{c}\text { Newcastle } \\
\text { disease virus }\end{array}$ & MEDI5395 & Durvalumab & PD-L1 & I & Advanced Solid Tumors \\
\hline NCT04301011 & Vaccinia & TBio-6517 & Pembrolizumab & PD-1 & I, II & $\begin{array}{l}\text { Triple Negative Breast Cancer Microsatellite Stable } \\
\text { Colorectal Cancer }\end{array}$ \\
\hline NCT04735978 & HSV & RP3 & Anti-PD-1 mAb & PD-1 & I & Advanced Solid Tumor \\
\hline NCT04348916 & HSV & ONCR-177 & Pembrolizumab & PD-1 & I & Advanced Solid Tumors \\
\hline NCT03294083 & Vaccinia & Pexa Vec & Cemiplimab & PD-1 & I, II & Renal Cell Carcinoma \\
\hline NCT04755543 & HSV & $\mathrm{OH} 2$ & LP002 & PD-1 & I & Digestive System Neoplasms \\
\hline NCT04386967 & HSV & $\mathrm{OH} 2$ & Keytruda & PD-1 & I, II & Solid Tumors, Melanoma \\
\hline NCT04616443 & HSV & $\mathrm{OH} 2$ & HX008 & PD-1 & I, II & Melanoma \\
\hline NCT03866525 & HSV & $\mathrm{OH} 2$ & HX008 & PD-1 & I, II & Solid Tumors, Gastrointestinal Cancer \\
\hline \multirow{2}{*}{ NCT03206073 } & \multirow{2}{*}{ Vaccinia } & \multirow{2}{*}{ Pexa-Vec } & Durvalumab & PD-L1 & \multirow[t]{2}{*}{ I, II } & \multirow[t]{2}{*}{ Colorectal Neoplasms } \\
\hline & & & Tremelimumab & CTLA-4 & & \\
\hline NCT04665362 & Alphavirus & M1 & SHR-1210 & PD-1 & I & Advanced/Metastatic Hepatocellular Carcinoma \\
\hline NCT04685499 & Adenovirus & OBP-301 & Pembrolizumab & PD-1 & II & HNSCC \\
\hline
\end{tabular}

In addition to these mainstream ICBs, a range of other immune targets have been identified for reprogramming these suppressive myeloid cell types towards an antitumor phenotype. Here, CSF1R is the most widely explored target followed by TLR-4, TLR- 
7, TLR-8, TLR-9, CD40, CD47, and SIRP $\alpha$ [133-135]. Other targets such as BTK, CCR2, and RIP are also getting appreciated [99,136-138]. A list of clinical trials that exploit the targets for macrophage repolarization in synergy with ICB are listed in Table 4 and a list of immunological targets on macrophages are represented in Figure 3.

Table 4. List of clinical trials targeting TAMs in combination with immune checkpoint blockade therapies for various cancers.

\begin{tabular}{|c|c|c|c|c|c|c|}
\hline \multirow{2}{*}{ Trial } & \multicolumn{2}{|c|}{ TAM-Directed Agent } & \multicolumn{2}{|c|}{ ICB Therapy } & \multirow{2}{*}{ Phase (S) } & \multirow{2}{*}{ Cancer (S) } \\
\hline & Agent & Target & Agent & Target & & \\
\hline NCT02323191 & Emactuzumab & CSF1R & Atezolizumab & PD-L1 & I & Locally advanced or metastatic solid tumors \\
\hline NCT02880371 & ARRY-382 & CSF1R & Pembrolizumab & PD-1 & $\mathrm{I} / \mathrm{II}$ & Advanced solid tumors \\
\hline NCT02777710 & Pexidartinib & CSF1R & Durvalumab & PD-L1 & I & $\begin{array}{l}\text { Colorectal cancer; Pancreatic cancer; Metastatic cancer; } \\
\text { Advanced cancer }\end{array}$ \\
\hline NCT03238027 & SNFX-6352 & CSF1R & Durvalumab & PD-L1 & $\mathrm{I}$ & $\begin{array}{c}\text { Solid tumor; Metastatic tumor; Locally advanced } \\
\text { malignant neoplasm; Unresectable malignant } \\
\text { neoplasm }\end{array}$ \\
\hline NCT02829723 & BLZ945 & CSF1R & PDR001 & PD-1 & $\mathrm{I} / \mathrm{II}$ & Advanced solid tumors \\
\hline NCT03158272 & Cabiralizumab & CSF1R & Nivolumab & PD-1 & I & Advanced malignancies \\
\hline NCT02713529 & AMG820 & CSF1R & Pembrolizumab & PD-1 & I/II & $\begin{array}{l}\text { Pancreatic cancer; Colorectal cancer; Non-small cell } \\
\text { lung cancer }\end{array}$ \\
\hline NCT03123783 & APX005M & CD40 & Nivolumab & PD-1 & $\mathrm{I} / \mathrm{II}$ & Non-small cell lung cancer; Metastatic melanoma \\
\hline NCT02304393 & Selicrelumab & CD40 & Atezolizumab & PD-L1 & I & Solid tumors \\
\hline NCT02637531 & IPI-549 & PI3K $\gamma$ & Nivolumab & PD-1 & I & $\begin{array}{l}\text { Advanced solid tumor; non-small cell lung cancer; } \\
\text { melanoma; breast cancer }\end{array}$ \\
\hline \multirow{4}{*}{ NCT02890368 } & \multirow{4}{*}{ TTI-621 } & \multirow{4}{*}{$\operatorname{SIRP} \alpha$} & Nivolumab & PD-1 & \multirow{4}{*}{ I } & \multirow{4}{*}{$\begin{array}{l}\text { Solid tumors; melanoma; merkel-cell carcinoma; } \\
\text { squamous cell carcinoma; breast carcinoma }\end{array}$} \\
\hline & & & Pembrolizumab & PD-1 & & \\
\hline & & & Atezolizumab & PD-L1 & & \\
\hline & & & Durvalumab & PD-L1 & & \\
\hline \multirow{2}{*}{ NCT03530683 } & \multirow{2}{*}{ TTI-621 } & \multirow{2}{*}{$\operatorname{SIRP} \alpha$} & Nivolumab & PD-1 & \multirow{2}{*}{ I } & \multirow{2}{*}{ Lymphoma; myeloma } \\
\hline & & & Pembrolizumab & PD-1 & & \\
\hline NCT03681951 & GSK3145095 & RIP & Pembrolizumab & PD-1 & $\mathrm{I} / \mathrm{II}$ & Neoplasms; pancreatic \\
\hline NCT03435640 & NKTR262 & TLR7/8 & Nivolumab & PD-1 & $\mathrm{I} / \mathrm{II}$ & $\begin{array}{l}\text { Melanoma; merkel cell carcinoma; breast cancer; renal } \\
\text { cell carcinoma; colorectal cancer }\end{array}$ \\
\hline NCT02880371 & ARRY-382 & CSF1R & Pembrolizumab & PD-1 & II & Advanced solid tumors \\
\hline NCT03153410 & IMC-CS4 & CSF1R & Pembrolizumab & PD-1 & I & PDAC \\
\hline NCT02526017 & $\begin{array}{c}\text { FPA008 } \\
\text { (Cabiralizumab) }\end{array}$ & CSF1R & Nivolumab & PD-1 & I & Advanced solid tumors \\
\hline NCT03708224 & Emactuzumab & CSF1R & Atezolizumab & PD-L1 & II & Advanced HNSCC \\
\hline NCT03184870 & \multirow{3}{*}{ BMS-813160 } & \multirow{3}{*}{ CCR2 } & \multirow{3}{*}{ Nivolumab } & \multirow{3}{*}{ PD-1 } & $\mathrm{I} / \mathrm{II}$ & PDAC, CRC \\
\hline NCT03496662 & & & & & $\mathrm{I} / \mathrm{II}$ & PDAC \\
\hline NCT03767582 & & & & & $\mathrm{I} / \mathrm{II}$ & Locally advanced PDAC \\
\hline NCT03447314 & GSK1795091 & TLR4 & Pembrolizumab & PD-1 & I & Advanced solid tumors \\
\hline NCT03445533 & IMO-2125 & TLR7/8 & Ipilimumab & CTLA-4 & III & Metastatic melanoma \\
\hline NCT02644967 & IMO-2125 & TLR7/8 & Pembrolizumab & PD-1 & $\mathrm{I} / \mathrm{II}$ & Metastatic melanoma \\
\hline NCT02521870 & \multirow{2}{*}{ SD101 } & \multirow{2}{*}{ TLR9 } & \multirow{2}{*}{ Pembrolizumab } & \multirow{2}{*}{ PD-1 } & $\mathrm{Ib} / \mathrm{II}$ & Metastatic melanoma, recurrent HNSCC \\
\hline NCT03007732 & & & & & $\mathrm{I} / \mathrm{II}$ & Solid tumors \\
\hline NCT03618641 & \multirow{2}{*}{ CMP-001 } & \multirow{2}{*}{ TLR9 } & Nivolumab & PD-1 & \multirow{2}{*}{ II } & Melanoma \\
\hline NCT03507699 & & & Ipilimumab & CTLA-4 & & Vielanoma \\
\hline NCT02403271 & Ibrutinib & BTK & Durvalumab & PD-L1 & $\mathrm{I} / \mathrm{II}$ & Relapsed or refractory solid tumors \\
\hline NCT02376699 & SEA-CD40 & CD40 & Pembrolizumab & PD-1 & I & Solid tumors \\
\hline NCT01103635 & CP-870, 893 & CD40 & Tremelimumab & CTLA-4 & I & Metastatic melanoma \\
\hline NCT02760797 & R07009879 & & Anti-PD-L1 & PD-L1 & I & Advanced solid tumors \\
\hline NCT02665416 & (Selicrelumab) & CD40 & $\begin{array}{l}\text { Bevacizumab/ } \\
\text { Vanucizumab }\end{array}$ & VEGF-A & I & Advanced solid tumors \\
\hline NCT02953782 & Hu5F9-G4 & CD47 & Cetuximab & EGFR & I & Advanced solid malignancies and colorectal carcinoma \\
\hline
\end{tabular}




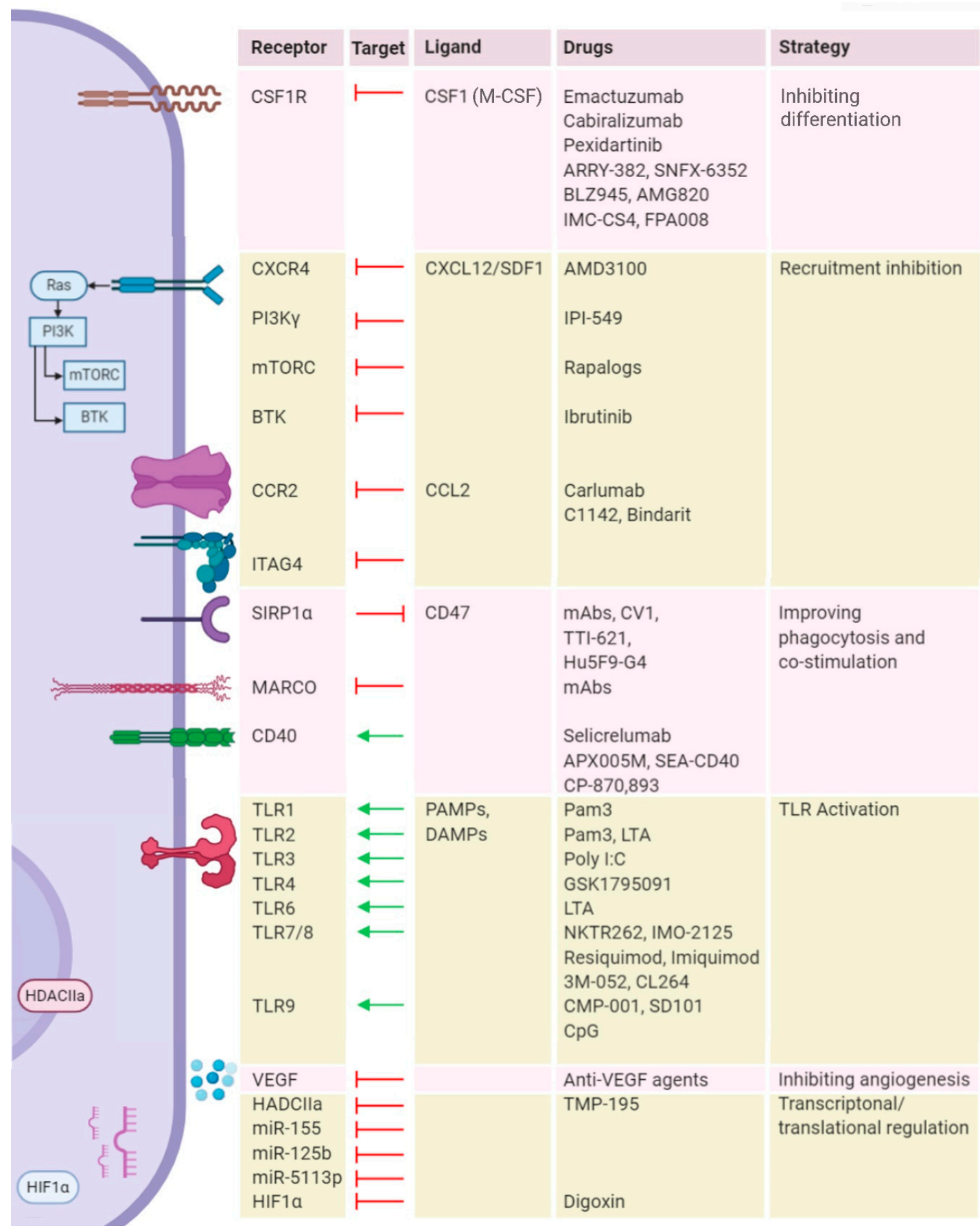

Figure 3. Current landscape of macrophage repolarization strategies. Various receptors, secretory molecules and regulatory pathways that skew macrophages to M2 state are lined on the left, and the respective therapeutic targets, their ligands, targeting strategies, and therapeutic agents are listed in the corresponding table on the right. Abbreviations: CSF1R: Colony-stimulating factor 1 receptor; CSF1: Colony-stimulating factor 1; M-CSF: Macrophage colony-stimulating factor; CXCR4: C-X-C chemokine receptor type 4; CXCL12: C-X-C motif chemokine ligand 12; SDF1: stromal cell-derived factor 1 (SDF1); PI3K: Phosphoinositide 3-kinase; mTORC: Mammalian target of rapamycin complex; BTK: Bruton's tyrosine kinase; CCR2: C-C chemokine receptor type 2; CCL2: C-C Motif chemokine ligand 2; ITAG: Integrin alpha gamma; SIRP1 $\alpha$ : signal regulatory protein alpha; MARCO: Macrophage receptor with collagenous structure; TLR: Toll-like receptor; CD: Cluster of differentiation; PAMPs: Pathogen-activated molecular patterns; DAMPs: Damage-associated molecular patterns; VEGF: Vascular endothelial growth factor; HDACIIa: Histone deacetylase class IIa; HIF1 $\alpha$ : Hypoxia-inducible factor 1-alpha. 


\section{Conclusions}

Reovirus represents a promising oncolytic agent, and its ability to drive an adaptive antitumor $\mathrm{T}$ cell response makes it an increasingly attractive immunotherapeutic. However, the efficacy of reovirus-based therapies remains suboptimal due to the highly suppressive effects of the TME. In particular, tumor-infiltrating myeloid cell populations such TAMs and MDSCs significantly contribute to these immunosuppressive effects using a variety of processes, including the production of anti-inflammatory cytokines, metabolic dysregulation, and T cell suppression. These TAM- and MDSC-based mechanisms hinder the efficacy of reovirus therapy but can be therapeutically targeted via blocking myeloid cell recruitment, depleting myeloid cell populations in the TME, reprogramming tumor or myeloid cell metabolism, and correcting aberrant cellular signaling pathways. The efficacy of many of these approaches is yet to be described in a reovirus-specific manner; therefore, further investigations testing the combination of reovirus and the TAM-/MDSC-targeting strategies promise to develop novel anticancer options.

Author Contributions: Conceptualization, M.A.G., V.K., S.G.; data collection, V.K. and M.A.G.; writing, M.A.G. and V.K.; review and editing, S.G. All authors have read and agreed to the published version of the manuscript.

Funding: V.K. is supported through the Cancer Research Training Program (CRTP) of the Beatrice Hunter Cancer Research Institute (BHCRI), with funds provided by the Motorcycle Ride for Dad through the Dalhousie Medical Research Foundation (DMRF). M.A.G. is supported through the Cancer Research Training Program (CRTP) of Beatrice Hunter Cancer Research Institute (BHCRI), with funds provided by the QEII Health Sciences Centre Foundation and GIVETOLIVE Becky Beaton Award, the Nova Scotia Graduate Scholarship (NSGS), and Killam Doctoral Scholarship. S.G. is supported by research grants from Canadian Institutes for Health research (CIHR) and Dalhousie Medical Research Foundation (DMRF).

Institutional Review Board Statement: Not applicable.

Informed Consent Statement: Not applicable.

Data Availability Statement: Not applicable.

Acknowledgments: Figures created with BioRender.com

Conflicts of Interest: The authors declare no conflict of interest.

\section{References}

1. Hanahan, D.; Weinberg, R.A. Hallmarks of cancer: The next generation. Cell 2011, 144, 646-674. [CrossRef] [PubMed]

2. Whiteside, T.L. The tumor microenvironment and its role in promoting tumor growth. Oncogene 2008, 27, 5904-5912. [CrossRef] [PubMed]

3. Gujar, S.; Pol, J.G.; Kroemer, G. Heating it up: Oncolytic viruses make tumors 'hot' and suitable for checkpoint blockade immunotherapies. Oncoimmunology 2018, 7, e1442169. [CrossRef] [PubMed]

4. Murphy, J.P.; Kim, Y.; Clements, D.R.; Konda, P.; Schuster, H.; Kowalewski, D.J.; Paulo, J.A.; Cohen, A.M.; Stevanovic, S.; Gygi, S.P.; et al. Therapy-Induced MHC I Ligands Shape Neo-Antitumor CD8 T Cell Responses during Oncolytic Virus-Based Cancer Immunotherapy. J. Proteome Res. 2019, 18, 2666-2675. [CrossRef]

5. Gujar, S.; Bell, J.; Diallo, J.S. SnapShot: Cancer Immunotherapy with Oncolytic Viruses. Cell 2019, 176, 1240. [CrossRef] [PubMed]

6. Gujar, S.; Pol, J.G.; Kim, Y.; Lee, P.W.; Kroemer, G. Antitumor Benefits of Antiviral Immunity: An Underappreciated Aspect of Oncolytic Virotherapies. Trends Immunol. 2018, 39, 209-221. [CrossRef]

7. Gonzalez, H.; Hagerling, C.; Werb, Z. Roles of the immune system in cancer: From tumor initiation to metastatic progression. Genes Dev. 2018, 32, 1267-1284. [CrossRef] [PubMed]

8. Maroun, J.; Muñoz-Alía, M.; Ammayappan, A.; Schulze, A.; Peng, K.W.; Russell, S. Designing and building oncolytic viruses. Future Virol. 2017, 12, 193-213. [CrossRef]

9. Zhang, B.; Wang, X.; Cheng, P. Remodeling of Tumor Immune Microenvironment by Oncolytic Viruses. Front. Oncol. 2021, 10, 3478. [CrossRef]

10. Kozak, R.; Hattin, L.; Biondi, M.; Corredor, J.; Walsh, S.; Xue-Zhong, M.; Manuel, J.; McGilvray, I.; Morgenstern, J.; Lusty, E.; et al. Replication and Oncolytic Activity of an Avian Orthoreovirus in Human Hepatocellular Carcinoma Cells. Viruses 2017, 9, 90. [CrossRef] 
11. Cai, R.; Meng, G.; Li, Y.; Wang, W.; Diao, Y.; Zhao, S.; Feng, Q.; Tang, Y. The oncolytic efficacy and safety of avian reovirus and its dynamic distribution in infected mice. Exp. Biol. Med. 2019, 244, 983-991. [CrossRef] [PubMed]

12. Shmulevitz, M.; Marcato, P.; Lee, P.W.K. Unshackling the links between reovirus oncolysis, Ras signaling, translational control and cancer. Oncogene 2005, 24, 7720-7728. [CrossRef]

13. Gujar, S.; Dielschneider, R.; Clements, D.; Helson, E.; Shmulevitz, M.; Marcato, P.; Pan, D.; Pan, L.Z.; Ahn, D.G.; Alawadhi, A.; et al. Multifaceted therapeutic targeting of ovarian peritoneal carcinomatosis through virus-induced immunomodulation. Mol. Ther. 2013, 21, 338-347. [CrossRef] [PubMed]

14. Gujar, S.A.; Lee, P.W.K. Oncolytic virus-mediated reversal of impaired tumor antigen presentation. Front. Oncol. 2014, 4 APR, 77. [CrossRef]

15. Gujar, S.A.; Clements, D.; Dielschneider, R.; Helson, E.; Marcato, P.; Lee, P.W.K. Gemcitabine enhances the efficacy of reovirusbased oncotherapy through anti-tumour immunological mechanisms. Br. J. Cancer 2014, 110, 83-93. [CrossRef]

16. Gujar, S.A.; Marcato, P.; Pan, D.; Lee, P.W.K. Reovirus virotherapy overrides tumor antigen presentation evasion and promotes protective antitumor immunity. Mol. Cancer Ther. 2010, 9, 2924-2933. [CrossRef]

17. White, C.L.; Twigger, K.R.; Vidal, L.; De Bono, J.S.; Coffey, M.; Heinemann, L.; Morgan, R.; Merrick, A.; Errington, F.; Vile, R.G.; et al. Characterization of the adaptive and innate immune response to intravenous oncolytic reovirus (Dearing type 3) during a phase I clinical trial. Gene Ther. 2008, 15, 911-920. [CrossRef]

18. Ginhoux, F; Jung, S. Monocytes and macrophages: Developmental pathways and tissue homeostasis. Nat. Rev. Immunol. 2014, 14, 392-404. [CrossRef] [PubMed]

19. Hirayama, D.; Iida, T.; Nakase, H. The Phagocytic Function of Macrophage-Enforcing Innate Immunity and Tissue Homeostasis. Int. J. Mol. Sci. 2017, 19, 92. [CrossRef]

20. Zhou, J.; Tang, Z.; Gao, S.; Li, C.; Feng, Y.; Zhou, X. Tumor-Associated Macrophages: Recent Insights and Therapies. Front. Oncol. 2020, 10, 188. [CrossRef]

21. Lacey, D.C.; Achuthan, A.; Fleetwood, A.J.; Dinh, H.; Roiniotis, J.; Scholz, G.M.; Chang, M.W.; Beckman, S.K.; Cook, A.D.; Hamilton, J.A. Defining GM-CSF- and Macrophage-CSF-Dependent Macrophage Responses by In Vitro Models. J. Immunol. 2012, 188, 5752-5765. [CrossRef]

22. Martinez, F.O.; Gordon, S. The M1 and M2 paradigm of macrophage activation: Time for reassessment. F1000Prime Rep. 2014, 6. [CrossRef] [PubMed]

23. Ushach, I.; Zlotnik, A. Biological role of granulocyte macrophage colony-stimulating factor (GM-CSF) and macrophage colonystimulating factor (M-CSF) on cells of the myeloid lineage. J. Leukoc. Biol. 2016, 100, 481-489. [CrossRef]

24. Hamilton, T.A.; Zhao, C.; Pavicic, P.G.; Datta, S. Myeloid colony-stimulating factors as regulators of macrophage polarization. Front. Immunol. 2014, 5, 554. [CrossRef]

25. Viola, A.; Munari, F.; Sánchez-Rodríguez, R.; Scolaro, T.; Castegna, A. The metabolic signature of macrophage responses. Front. Immunol. 2019, 10, 1462. [CrossRef]

26. O'Neill, L.A.J. A Metabolic Roadblock in Inflammatory Macrophages. Cell Rep. 2016, 17, 625-626. [CrossRef]

27. Mantovani, A.; Marchesi, F.; Malesci, A.; Laghi, L.; Allavena, P. Tumour-associated macrophages as treatment targets in oncology. Nat. Rev. Clin. Oncol. 2017, 14, 399-416. [CrossRef]

28. Fares, C.M.; Van Allen, E.M.; Drake, C.G.; Allison, J.P.; Hu-Lieskovan, S. Mechanisms of Resistance to Immune Checkpoint Blockade: Why Does Checkpoint Inhibitor Immunotherapy Not Work for All Patients? Am. Soc. Clin. Oncol. Educ. Book. Am. Soc. Clin. Oncol. Annu. Meet. 2019, 39, 147-164. [CrossRef] [PubMed]

29. Pender, A.; Titmuss, E.; Pleasance, E.D.; Fan, K.Y.; Pearson, H.; Brown, S.D.; Grisdale, C.J.; Topham, J.T.; Shen, Y.; Bonakdar, M.; et al. Genome and transcriptome biomarkers of response to immune checkpoint inhibitors in advanced solid tumors. Clin. Cancer Res. 2021, 27, 202-212. [CrossRef] [PubMed]

30. Jayasingam, S.D.; Citartan, M.; Thang, T.H.; Mat Zin, A.A.; Ang, K.C.; Ch'ng, E.S. Evaluating the Polarization of Tumor-Associated Macrophages Into M1 and M2 Phenotypes in Human Cancer Tissue: Technicalities and Challenges in Routine Clinical Practice. Front. Oncol. 2020, 9, 1512. [CrossRef]

31. Xue, J.; Schmidt, S.V.; Sander, J.; Draffehn, A.; Krebs, W.; Quester, I.; DeNardo, D.; Gohel, T.D.; Emde, M.; Schmidleithner, L.; et al. Transcriptome-Based Network Analysis Reveals a Spectrum Model of Human Macrophage Activation. Immunity 2014, 40, 274-288. [CrossRef]

32. Kiss, M.; Van Gassen, S.; Movahedi, K.; Saeys, Y.; Laoui, D. Myeloid cell heterogeneity in cancer: Not a single cell alike. Cell. Immunol. 2018, 330, 188-201. [CrossRef]

33. Locati, M.; Curtale, G.; Mantovani, A. Diversity, Mechanisms, and Significance of Macrophage Plasticity. Annu. Rev. Pathol. Mech. Dis. 2020, 15, 123-147. [CrossRef] [PubMed]

34. Gabrilovich, D.I.; Nagaraj, S. Myeloid-derived suppressor cells as regulators of the immune system. Nat. Rev. Immunol. 2009, 9 , 162-174. [CrossRef] [PubMed]

35. Schmid, M.C.; Franco, I.; Kang, S.W.; Hirsch, E.; Quilliam, L.A.; Varner, J.A. PI3-Kinase $\gamma$ Promotes Rap1a-Mediated Activation of Myeloid Cell Integrin $\alpha 4 \beta 1$, Leading to Tumor Inflammation and Growth. PLoS ONE 2013, 8, e60226. [CrossRef] [PubMed]

36. Lesokhin, A.M.; Hohl, T.M.; Kitano, S.; Cortez, C.; Hirschhorn-Cymerman, D.; Avogadri, F.; Rizzuto, G.A.; Lazarus, J.J.; Pamer, E.G.; Houghton, A.N.; et al. Monocytic CCR2 + myeloid-derived suppressor cells promote immune escape by limiting activated CD8 T-cell infiltration into the tumor microenvironment. Cancer Res. 2012, 72, 876-886. [CrossRef] [PubMed] 
37. Condamine, T.; Ramachandran, I.; Youn, J.-I.; Gabrilovich, D.I. Regulation of Tumor Metastasis by Myeloid-Derived Suppressor Cells. Annu. Rev. Med. 2015, 66, 97-110. [CrossRef] [PubMed]

38. Gabrilovich, D.I. Myeloid-derived suppressor cells. Cancer Immunol. Res. 2017, 5, 3-8. [CrossRef]

39. Groth, C.; Hu, X.; Weber, R.; Fleming, V.; Altevogt, P.; Utikal, J.; Umansky, V. Immunosuppression mediated by myeloid-derived suppressor cells (MDSCs) during tumour progression. Br. J. Cancer 2019, 120, 16-25. [CrossRef]

40. Condamine, T.; Gabrilovich, D.I. Molecular mechanisms regulating myeloid-derived suppressor cell differentiation and function. Trends Immunol. 2011, 32, 19-25. [CrossRef]

41. Davidov, V.; Jensen, G.; Mai, S.; Chen, S.H.; Pan, P.Y. Analyzing One Cell at a TIME: Analysis of Myeloid Cell Contributions in the Tumor Immune Microenvironment. Front. Immunol. 2020, 11, 1842. [CrossRef] [PubMed]

42. Wang, P.F.; Song, S.Y.; Wang, T.J.; Ji, W.J.; Li, S.W.; Liu, N.; Yan, C.X. Prognostic role of pretreatment circulating MDSCs in patients with solid malignancies: A meta-analysis of 40 studies. Oncoimmunology 2018, 7, e1494113. [CrossRef] [PubMed]

43. Fultang, N.; Li, X.; Li, T.; Chen, Y.H. Myeloid-Derived Suppressor Cell Differentiation in Cancer: Transcriptional Regulators and Enhanceosome-Mediated Mechanisms. Front. Immunol. 2021, 11, 3493. [CrossRef]

44. Beury, D.W.; Parker, K.H.; Nyandjo, M.; Sinha, P.; Carter, K.A.; Ostrand-Rosenberg, S. Cross-talk among myeloid-derived suppressor cells, macrophages, and tumor cells impacts the inflammatory milieu of solid tumors. J. Leukoc. Biol. 2014, 96, 1109-1118. [CrossRef]

45. Murdoch, C.; Muthana, M.; Coffelt, S.B.; Lewis, C.E. The role of myeloid cells in the promotion of tumour angiogenesis. Nat. Rev. Cancer 2008, 8, 618-631. [CrossRef]

46. Petty, A.J.; Yang, Y. Tumor-associated macrophages: Implications in cancer immunotherapy. Immunotherapy 2017, 9, 289-302. [CrossRef]

47. Guerriero, J.L. Macrophages: The Road Less Traveled, Changing Anticancer Therapy. Trends Mol. Med. 2018, 24, 472-489. [CrossRef] [PubMed]

48. Noy, R.; Pollard, J.W. Tumor-Associated Macrophages: From Mechanisms to Therapy. Immunity 2014, 41, 49-61. [CrossRef]

49. Vitale, I.; Manic, G.; Coussens, L.M.; Kroemer, G.; Galluzzi, L. Macrophages and Metabolism in the Tumor Microenvironment. Cell Metab. 2019, 30, 36-50. [CrossRef] [PubMed]

50. Kelly, P.M.A.; Davison, R.S.; Bliss, E.; McGee, J.O.D. Macrophages in human breast disease: A quantitative immunohistochemical study. Br. J. Cancer 1988, 57, 174-177. [CrossRef]

51. Hanada, T.; Nakagawa, M.; Emoto, A.; Nomura, T.; Nasu, N.; Nomura, Y. Prognostic value of tumor-associated macrophage count in human bladder cancer. Int. J. Urol. 2000, 7, 263-269. [CrossRef]

52. Ciavarra, R.P.; Taylor, L.; Greene, A.R.; Yousefieh, N.; Horeth, D.; Van Rooijen, N.; Steel, C.; Gregory, B.; Birkenbach, M.; Sekellick, M. Impact of macrophage and dendritic cell subset elimination on antiviral immunity, viral clearance and production of type 1 interferon. Virology 2005, 342, 177-189. [CrossRef]

53. Murray, P.J.; Allen, J.E.; Biswas, S.K.; Fisher, E.A.; Gilroy, D.W.; Goerdt, S.; Gordon, S.; Hamilton, J.A.; Ivashkiv, L.B.; Lawrence, T.; et al. Macrophage Activation and Polarization: Nomenclature and Experimental Guidelines. Immunity 2014, 41, 14-20. [CrossRef] [PubMed]

54. Sica, A.; Bronte, V. Altered macrophage differentiation and immune dysfunction in tumor development. J. Clin. Investig. 2007, 117, 1155-1166. [CrossRef] [PubMed]

55. Bandura, D.R.; Baranov, V.I.; Ornatsky, O.I.; Antonov, A.; Kinach, R.; Lou, X.; Pavlov, S.; Vorobiev, S.; Dick, J.E.; Tanner, S.D. Mass cytometry: Technique for real time single cell multitarget immunoassay based on inductively coupled plasma time-of-flight mass spectrometry. Anal. Chem. 2009, 81, 6813-6822. [CrossRef] [PubMed]

56. Saeys, Y.; Van Gassen, S.; Lambrecht, B.N. Computational flow cytometry: Helping to make sense of high-dimensional immunology data. Nat. Rev. Immunol. 2016, 16, 449-462. [CrossRef]

57. Cassetta, L.; Fragkogianni, S.; Sims, A.H.; Swierczak, A.; Forrester, L.M.; Zhang, H.; Soong, D.Y.H.; Cotechini, T.; Anur, P.; Lin, E.Y.; et al. Human Tumor-Associated Macrophage and Monocyte Transcriptional Landscapes Reveal Cancer-Specific Reprogramming, Biomarkers, and Therapeutic Targets. Cancer Cell 2019, 35, 588-602. [CrossRef]

58. Zhu, X.D.; Zhang, J.B.; Zhuang, P.Y.; Zhu, H.G.; Zhang, W.; Xiong, Y.Q.; Wu, W.Z.; Wang, L.; Tang, Z.Y.; Sun, H.C. High expression of macrophage colony-stimulating factor in peritumoral liver tissue is associated with poor survival after curative resection of hepatocellular carcinoma. J. Clin. Oncol. 2008, 26, 2707-2716. [CrossRef]

59. Lin, E.Y.; Nguyen, A.V.; Russell, R.G.; Pollard, J.W. Colony-stimulating factor 1 promotes progression of mammary tumors to malignancy. J. Exp. Med. 2001, 193, 727-739. [CrossRef]

60. Ruffell, B.; Affara, N.I.; Coussens, L.M. Differential macrophage programming in the tumor microenvironment. Trends Immunol. 2012, 33, 119-126. [CrossRef]

61. Wyckoff, J.; Wang, W.; Lin, E.Y.; Wang, Y.; Pixley, F.; Stanley, E.R.; Graf, T.; Pollard, J.W.; Segall, J.; Condeelis, J. A paracrine loop between tumor cells and macrophages is required for tumor cell migration in mammary tumors. Cancer Res. 2004, 64, 7022-7029. [CrossRef]

62. Qian, B.Z.; Pollard, J.W. Macrophage Diversity Enhances Tumor Progression and Metastasis. Cell 2010, 141, 39-51. [CrossRef]

63. Mizutani, K.; Sud, S.; McGregor, N.A.; Martinovski, G.; Rice, B.T.; Craig, M.J.; Varsos, Z.S.; Roca, H.; Pienta, K.J. The chemokine CCL2 increases prostate tumor growth and bone metastasis through macrophage and osteoclast recruitment. Neoplasia 2009, 11, 1235-1242. [CrossRef] [PubMed] 
64. Kitamura, T.; Qian, B.Z.; Soong, D.; Cassetta, L.; Noy, R.; Sugano, G.; Kato, Y.; Li, J.; Pollard, J.W. CCL2-induced chemokine cascade promotes breast cancer metastasis by enhancing retention of metastasis-associated macrophages. J. Exp. Med. 2015, 212, 1043-1059. [CrossRef] [PubMed]

65. Serafini, P.; Carbley, R.; Noonan, K.A.; Tan, G.; Bronte, V.; Borrello, I. High-dose granulocyte-macrophage colony-stimulating factor-producing vaccines impair the immune response through the recruitment of myeloid suppressor cells. Cancer Res. 2004, 64, 6337-6343. [CrossRef] [PubMed]

66. Fridlender, Z.G.; Sun, J.; Kim, S.; Kapoor, V.; Cheng, G.; Ling, L.; Worthen, G.S.; Albelda, S.M. Polarization of Tumor-Associated Neutrophil Phenotype by TGF- $\beta$ : “N1" versus “N2" TAN. Cancer Cell 2009, 16, 183-194. [CrossRef] [PubMed]

67. Jiffry, J.; Thavornwatanayong, T.; Rao, D.; Fogel, E.J.; Saytoo, D.; Nahata, R.; Guzik, H.; Chaudhary, I.; Augustine, T.; Goel, S.; et al. Oncolytic reovirus (pelareorep) induces autophagy in KRAS-mutated colorectal cancer. Clin. Cancer Res. 2021, 27, 865-876. [CrossRef]

68. Maitra, R.; Seetharam, R.; Tesfa, L.; Augustine, T.A.; Klampfer, L.; Coffey, M.C.; Mariadason, J.M.; Goel, S. Oncolytic reovirus preferentially induces apoptosis in KRAS mutant colorectal cancer cells, and synergizes with irinotecan. Oncotarget 2014, 5, 2807-2819. [CrossRef]

69. Villalona-Calero, M.A.; Lam, E.; Otterson, G.A.; Zhao, W.; Timmons, M.; Subramaniam, D.; Hade, E.M.; Gill, G.M.; Coffey, M.; Selvaggi, G.; et al. Oncolytic reovirus in combination with chemotherapy in metastatic or recurrent non-small cell lung cancer patients with KRAS-activated tumors. Cancer 2016, 122, 875-883. [CrossRef]

70. Danthi, P.; Guglielmi, K.M.; Kirchner, E.; Mainou, B.; Stehle, T.; Dermody, T.S. From Touchdown to Transcription: The Reovirus Cell Entry Pathway. In Cell Entry by Non-Enveloped Viruses; Springer: Berlin, Heidelberg, 2010; Volume 343, pp. 91-119.

71. Müller, L.; Berkeley, R.; Barr, T.; Ilett, E.; Errington-Mais, F. Past, Present and Future of Oncolytic Reovirus. Cancers (Basel) 2020, 12, 3219. [CrossRef]

72. Galluzzi, L.; Vitale, I.; Aaronson, S.A.; Abrams, J.M.; Adam, D.; Agostinis, P.; Alnemri, E.S.; Altucci, L.; Amelio, I.; Andrews, D.W.; et al. Molecular mechanisms of cell death: Recommendations of the Nomenclature Committee on Cell Death 2018. Cell Death Differ. 2018, 25, 486-541. [CrossRef]

73. Ikeda, Y.; Nishimura, G.; Yanoma, S.; Kubota, A.; Furukawa, M.; Tsukuda, M. Reovirus oncolysis in human head and neck squamous carcinoma cells. Auris Nasus Larynx 2004, 31, 407-412. [CrossRef]

74. Yuan, J.; Kroemer, G. Alternative cell death mechanisms in development and beyond. Genes Dev. 2010, 24, 2592-2602. [CrossRef]

75. Thirukkumaran, C.; Morris, D.G. Oncolytic viral therapy using reovirus. Methods Mol. Biol. 2015, 1317, 187-223. [CrossRef] [PubMed]

76. Giacomantonio, M.A.; Sterea, A.M.; Kim, Y.; Paulo, J.A.; Clements, D.R.; Kennedy, B.E.; Bydoun, M.J.; Shi, G.; Waisman, D.M.; Gygi, S.P.; et al. Quantitative Proteome Responses to Oncolytic Reovirus in GM-CSF-and M-CSF-Differentiated Bone Marrow-Derived Cells. J. Proteome Res. 2020, 19, 708-718. [CrossRef] [PubMed]

77. Clements, D.R.; Murphy, J.P.; Sterea, A.; Kennedy, B.E.; Kim, Y.; Helson, E.; Almasi, S.; Holay, N.; Konda, P.; Paulo, J.A.; et al. Quantitative Temporal in Vivo Proteomics Deciphers the Transition of Virus-Driven Myeloid Cells into M2 Macrophages. J. Proteome Res. 2017, 16, 3391-3406. [CrossRef] [PubMed]

78. Fulci, G.; Breymann, L.; Gianni, D.; Kurozomi, K.; Rhee, S.S.; Yu, J.; Kaur, B.; Louis, D.N.; Weissleder, R.; Caligiuri, M.A.; et al. Cyclophosphamide enhances glioma virotherapy by inhibiting innate immune responses. Proc. Natl. Acad. Sci. USA 2006, 103, 12873-12878. [CrossRef] [PubMed]

79. Tan, Z.; Liu, L.; Chiu, M.S.; Cheung, K.W.; Yan, C.W.; Yu, Z.; Lee, B.K.; Liu, W.; Man, K.; Chen, Z. Virotherapy-recruited PMN-MDSC infiltration of mesothelioma blocks antitumor CTL by IL-10-mediated dendritic cell suppression. Oncoimmunology 2019, 8, e1518672. [CrossRef] [PubMed]

80. Kennedy, B.E.; Sadek, M.; Gujar, S.A. Targeted Metabolic Reprogramming to Improve the Efficacy of Oncolytic Virus Therapy. Mol. Ther. 2020, 28, 1417-1421. [CrossRef] [PubMed]

81. Farhood, B.; Najafi, M.; Mortezaee, K. CD8+ cytotoxic T lymphocytes in cancer immunotherapy: A review. J. Cell. Physiol. 2019, 234, 8509-8521. [CrossRef]

82. Clements, D.R.; Sterea, A.M.; Kim, Y.; Helson, E.; Dean, C.A.; Nunokawa, A.; Coyle, K.M.; Sharif, T.; Marcato, P.; Gujar, S.A.; et al. Newly Recruited CD11b +, GR-1 +, Ly6C high Myeloid Cells Augment Tumor-Associated Immunosuppression Immediately following the Therapeutic Administration of Oncolytic Reovirus. J. Immunol. 2015, 194, 4397-4412. [CrossRef]

83. Gujar, S.A.; Clements, D.; Lee, P.W.K. Two is better than one: Complementing oncolytic virotherapy with gemcitabine to potentiate antitumor immune responses. Oncoimmunology 2014, 3. [CrossRef]

84. Katayama, Y.; Tachibana, M.; Kurisu, N.; Oya, Y.; Terasawa, Y.; Goda, H.; Kobiyama, K.; Ishii, K.J.; Akira, S.; Mizuguchi, H.; et al. Oncolytic Reovirus Inhibits Immunosuppressive Activity of Myeloid-Derived Suppressor Cells in a TLR3-Dependent Manner. J. Immunol. 2018, 200, 2987-2999. [CrossRef]

85. Parker, J.N.; Gillespie, G.Y.; Love, C.E.; Randall, S.; Whitley, R.J.; Markert, J.M. Engineered herpes simplex virus expressing IL-12 in the treatment of experimental murine brain tumors. Proc. Natl. Acad. Sci. USA 2000, 97, 2208-2213. [CrossRef]

86. Kleijn, A.; Kloezeman, J.; Treffers-Westerlaken, E.; Fulci, G.; Leenstra, S.; Dirven, C.; Debets, R.; Lamfers, M. The In Vivo Therapeutic Efficacy of the Oncolytic Adenovirus Delta24-RGD Is Mediated by Tumor-Specific Immunity. PLoS ONE 2014, 9 , e97495. [CrossRef] [PubMed] 
87. Tan, D.Q.; Zhang, L.; Ohba, K.; Ye, M.; Ichiyama, K.; Yamamoto, N. Macrophage response to oncolytic paramyxoviruses potentiates virus-mediated tumor cell killing. Eur. J. Immunol. 2016, 46, 919-928. [CrossRef]

88. Esaki, S.; Goshima, F.; Kimura, H.; Murakami, S.; Nishiyama, Y. Enhanced antitumoral activity of oncolytic herpes simplex virus with gemcitabine using colorectal tumor models. Int. J. Cancer 2013, 132, 1592-1601. [CrossRef] [PubMed]

89. Togashi, Y.; Shitara, K.; Nishikawa, H. Regulatory T cells in cancer immunosuppression-Implications for anticancer therapy. Nat. Rev. Clin. Oncol. 2019, 16, 356-371. [CrossRef] [PubMed]

90. Siret, C.; Collignon, A.; Silvy, F.; Robert, S.; Cheyrol, T.; André, P.; Rigot, V.; Iovanna, J.; van de Pavert, S.; Lombardo, D.; et al. Deciphering the Crosstalk Between Myeloid-Derived Suppressor Cells and Regulatory T Cells in Pancreatic Ductal Adenocarcinoma. Front. Immunol. 2020, 10, 3070. [CrossRef] [PubMed]

91. Lucca, L.E.; Dominguez-Villar, M. Modulation of regulatory T cell function and stability by co-inhibitory receptors. Nat. Rev. Immunol. 2020, 20, 680-693. [CrossRef]

92. Savage, P.A.; Klawon, D.E.J.; Miller, C.H. Regulatory T Cell Development. Annu. Rev. Immunol. 2020, 38, 421-453. [CrossRef] [PubMed]

93. Qian, B.Z.; Li, J.; Zhang, H.; Kitamura, T.; Zhang, J.; Campion, L.R.; Kaiser, E.A.; Snyder, L.A.; Pollard, J.W. CCL2 recruits inflammatory monocytes to facilitate breast-tumour metastasis. Nature 2011, 475, 222-225. [CrossRef] [PubMed]

94. Ren, G.; Zhao, X.; Wang, Y.; Zhang, X.; Chen, X.; Xu, C.; Yuan, Z.R.; Roberts, A.I.; Zhang, L.; Zheng, B.; et al. CCR2-dependent recruitment of macrophages by tumor-educated mesenchymal stromal cells promotes tumor development and is mimicked by TNF $\alpha$. Cell Stem Cell 2012, 11, 812-824. [CrossRef] [PubMed]

95. Fridlender, Z.G.; Buchlis, G.; Kapoor, V.; Cheng, G.; Sun, J.; Singhal, S.; Crisanti, C.; Wang, L.C.S.; Heitjan, D.; Snyder, L.A.; et al. CCL2 blockade augments cancer immunotherapy. Cancer Res. 2010, 70, 109-118. [CrossRef] [PubMed]

96. Bonapace, L.; Coissieux, M.M.; Wyckoff, J.; Mertz, K.D.; Varga, Z.; Junt, T.; Bentires-Alj, M. Cessation of CCL2 inhibition accelerates breast cancer metastasis by promoting angiogenesis. Nature 2014, 515, 130-133. [CrossRef] [PubMed]

97. Pathria, P.; Louis, T.L.; Varner, J.A. Targeting Tumor-Associated Macrophages in Cancer. Trends Immunol. 2019, 40, 310-327. [CrossRef] [PubMed]

98. Hughes, R.; Qian, B.Z.; Rowan, C.; Muthana, M.; Keklikoglou, I.; Olson, O.C.; Tazzyman, S.; Danson, S.; Addison, C.; Clemons, M.; et al. Perivascular M2 macrophages stimulate tumor relapse after chemotherapy. Cancer Res. 2015, 75, 3479-3491. [CrossRef]

99. Scala, S. Molecular pathways: Targeting the CXCR4-CXCL12 Axis-Untapped potential in the tumor microenvironment. Clin. Cancer Res. 2015, 21, 4278-4285. [CrossRef]

100. Teicher, B.A.; Fricker, S.P. CXCL12 (SDF-1)/CXCR4 pathway in cancer. Clin. Cancer Res. 2010, 16, 2927-2931. [CrossRef]

101. Zheng, X.; Turkowski, K.; Mora, J.; Brüne, B.; Seeger, W.; Weigert, A.; Savai, R. Redirecting tumor-associated macrophages to become tumoricidal effectors as a novel strategy for cancer therapy. Oncotarget 2017, 8, 48436-48452. [CrossRef]

102. Rogers, T.L.; Holen, I. Tumour macrophages as potential targets of bisphosphonates. J. Transl. Med. 2011, 9. [CrossRef] [PubMed]

103. Giraudo, E.; Inoue, M.; Hanahan, D. An amino-bisphosphonate targets MMP-9-expressing macrophages and angiogenesis to impair cervical carcinogenesis. J. Clin. Investig. 2004, 114, 623-633. [CrossRef]

104. Germano, G.; Frapolli, R.; Belgiovine, C.; Anselmo, A.; Pesce, S.; Liguori, M.; Erba, E.; Uboldi, S.; Zucchetti, M.; Pasqualini, F.; et al. Role of Macrophage Targeting in the Antitumor Activity of Trabectedin. Cancer Cell 2013, 23, 249-262. [CrossRef]

105. Denton, N.L.; Chen, C.Y.; Hutzen, B.; Currier, M.A.; Scott, T.; Nartker, B.; Leddon, J.L.; Wang, P.Y.; Srinivas, R.; Cassady, K.A.; et al. Myelolytic Treatments Enhance Oncolytic Herpes Virotherapy in Models of Ewing Sarcoma by Modulating the Immune Microenvironment. Mol. Ther. Oncolytics 2018, 11, 62-74. [CrossRef]

106. Fulci, G.; Dmitrieva, N.; Gianni, D.; Fontana, E.J.; Pan, X.; Lu, Y.; Kaufman, C.S.; Kaur, B.; Lawler, S.E.; Lee, R.J.; et al. Depletion of peripheral macrophages and brain microglia increases brain tumor titers of oncolytic viruses. Cancer Res. 2007, 67, 9398-9406. [CrossRef]

107. O'Neill, L.A.J. A Broken Krebs Cycle in Macrophages. Immunity 2015, 42, 393-394. [CrossRef]

108. Van den Bossche, J.; O’Neill, L.A.; Menon, D. Macrophage Immunometabolism: Where Are We (Going)? Trends Immunol. 2017, 38, 395-406. [CrossRef] [PubMed]

109. O’Neill, L.A.J.; Kishton, R.J.; Rathmell, J. A guide to immunometabolism for immunologists. Nat. Rev. Immunol. 2016, 16, 553-565. [CrossRef]

110. Jha, A.K.; Huang, S.C.C.; Sergushichev, A.; Lampropoulou, V.; Ivanova, Y.; Loginicheva, E.; Chmielewski, K.; Stewart, K.M.; Ashall, J.; Everts, B.; et al. Network integration of parallel metabolic and transcriptional data reveals metabolic modules that regulate macrophage polarization. Immunity 2015, 42, 419-430. [CrossRef] [PubMed]

111. Van den Bossche, J.; Baardman, J.; Otto, N.A.; van der Velden, S.; Neele, A.E.; van den Berg, S.M.; Luque-Martin, R.; Chen, H.J.; Boshuizen, M.C.S.; Ahmed, M.; et al. Mitochondrial Dysfunction Prevents Repolarization of Inflammatory Macrophages. Cell Rep. 2016, 17, 684-696. [CrossRef] [PubMed]

112. Huang, S.C.C.; Smith, A.M.; Everts, B.; Colonna, M.; Pearce, E.L.; Schilling, J.D.; Pearce, E.J. Metabolic Reprogramming Mediated by the mTORC2-IRF4 Signaling Axis Is Essential for Macrophage Alternative Activation. Immunity 2016, 45, 817-830. [CrossRef]

113. Kowal, J.; Kornete, M.; Joyce, J.A. Re-education of macrophages as a therapeutic strategy in cancer. Immunotherapy 2019, 11, 677-689. [CrossRef]

114. Barclay, A.N.; Van Den Berg, T.K. The interaction between signal regulatory protein alpha (SIRP $\alpha$ ) and CD47: Structure, function, and therapeutic target. Annu. Rev. Immunol. 2014, 32, 25-50. [CrossRef] 
115. Weiskopf, K.; Ring, A.M.; Ho, C.C.M.; Volkmer, J.P.; Levin, A.M.; Volkmer, A.K.; Özkan, E.; Fernhoff, N.B.; Van De Rijn, M.; Weissman, I.L.; et al. Engineered SIRP $\alpha$ variants as immunotherapeutic adjuvants to anticancer antibodies. Science 2013, 341, 88-91. [CrossRef]

116. Shi, G.; Yang, Q.; Zhang, Y.; Jiang, Q.; Lin, Y.; Yang, S.; Wang, H.; Cheng, L.; Zhang, X.; Li, Y.; et al. Modulating the Tumor Microenvironment via Oncolytic Viruses and CSF-1R Inhibition Synergistically Enhances Anti-PD-1 Immunotherapy. Mol. Ther. 2019, 27, 244-260. [CrossRef]

117. Cerullo, V.; Diaconu, I.; Romano, V.; Hirvinen, M.; Ugolini, M.; Escutenaire, S.; Holm, S.L.; Kipar, A.; Kanerva, A.; Hemminki, A. An oncolytic adenovirus enhanced for toll-like receptor 9 stimulation increases antitumor immune responses and tumor clearance. Mol. Ther. 2012, 20, 2076-2086. [CrossRef]

118. Eriksson, E.; Moreno, R.; Milenova, I.; Liljenfeldt, L.; Dieterich, L.C.; Christiansson, L.; Karlsson, H.; Ullenhag, G.; Mangsbo, S.M.; Dimberg, A.; et al. Activation of myeloid and endothelial cells by CD40L gene therapy supports T-cell expansion and migration into the tumor microenvironment. Gene Ther. 2017, 24, 92-103. [CrossRef]

119. Kemp, V.; van den Wollenberg, D.J.M.; Camps, M.G.M.; van Hall, T.; Kinderman, P.; Pronk-van Montfoort, N.; Hoeben, R.C. Arming oncolytic reovirus with GM-CSF gene to enhance immunity. Cancer Gene Ther. 2019, 26, 268-281. [CrossRef] [PubMed]

120. Breitbach, C.; Bell, J.C.; Hwang, T.-H.; Kirn, D.; Burke, J. The emerging therapeutic potential of the oncolytic immunotherapeutic Pexa-Vec (JX-594). Oncolytic Virotherapy 2015, 4, 25. [CrossRef]

121. Park, S.H.; Breitbach, C.J.; Lee, J.; Park, J.O.; Lim, H.Y.; Kang, W.K.; Moon, A.; Mun, J.H.; Sommermann, E.M.; Maruri Avidal, L.; et al. Phase $1 \mathrm{~b}$ Trial of Biweekly Intravenous Pexa-Vec (JX-594), an Oncolytic and Immunotherapeutic Vaccinia Virus in Colorectal Cancer. Mol. Ther. 2015, 23, 1532-1540. [CrossRef]

122. Cripe, T.P.; Ngo, M.C.; Geller, J.I.; Louis, C.U.; Currier, M.A.; Racadio, J.M.; Towbin, A.J.; Rooney, C.M.; Pelusio, A.; Moon, A.; et al. Phase 1 study of intratumoral Pexa-Vec (JX-594), an oncolytic and immunotherapeutic vaccinia virus, in pediatric cancer patients. Mol. Ther. 2015, 23, 602-608. [CrossRef]

123. Koch, M.; Lawler, S.; Chiocca, E. HSV-1 Oncolytic Viruses from Bench to Bedside: An Overview of Current Clinical Trials. Cancers (Basel) 2020, 12, 3514. [CrossRef]

124. Middleton, M.R.; Aroldi, F.; Sacco, J.; Milhem, M.M.; Curti, B.D.; Vanderwalde, A.M.; Baum, S.; Samson, A.; Pavlick, A.C.; Chesney, J.A.; et al. An open-label, single-arm, phase II clinical trial of RP1, an enhanced potency oncolytic herpes virus, combined with nivolumab in four solid tumor types: Initial results from the skin cancer cohorts. J. Clin. Oncol. 2020, 38, e22050. [CrossRef]

125. Pol, J.G.; Lévesque, S.; Workenhe, S.T.; Gujar, S.; Le Boeuf, F.; Clements, D.R.; Fahrner, J.E.; Fend, L.; Bell, J.C.; Mossman, K.L.; et al. Trial Watch: Oncolytic viro-immunotherapy of hematologic and solid tumors. Oncoimmunology 2018, 7. [CrossRef]

126. Pol, J.; Kroemer, G.; Galluzzi, L. First oncolytic virus approved for melanoma immunotherapy. Oncoimmunology 2016, 5, e1115641. [CrossRef]

127. Liu, B.L.; Robinson, M.; Han, Z.Q.; Branston, R.H.; English, C.; Reay, P.; McGrath, Y.; Thomas, S.K.; Thornton, M.; Bullock, P.; et al. ICP34.5 deleted herpes simplex virus with enhanced oncolytic, immune stimulating, and anti-tumour properties. Gene Ther. 2003, 10, 292-303. [CrossRef]

128. Liu, M.; Zhou, J.; Liu, X.; Feng, Y.; Yang, W.; Wu, F.; Cheung, O.K.W.; Sun, H.; Zeng, X.; Tang, W.; et al. Targeting monocyte-intrinsic enhancer reprogramming improves immunotherapy efficacy in hepatocellular carcinoma. Gut 2020, 69, 365-379. [CrossRef]

129. Chen, J.; Sun, H.W.; Yang, Y.Y.; Chen, H.T.; Yu, X.J.; Wu, W.C.; Xu, Y.T.; Jin, L.L.; Wu, X.J.; Xu, J.; et al. Reprogramming immunosuppressive myeloid cells by activated T cells promotes the response to anti-PD-1 therapy in colorectal cancer. Signal Transduct. Target. Ther. 2021, 6, 1-14. [CrossRef]

130. Pico De Coaña, Y.; Masucci, G.; Hansson, J.; Kiessling, R. Myeloid-derived suppressor cells and their role in CTLA-4 blockade therapy. Cancer Immunol. Immunother. 2014, 63, 977-983. [CrossRef]

131. Chesney, J.A.; Mitchell, R.A.; Yaddanapudi, K. Myeloid-derived suppressor cells-a new therapeutic target to overcome resistance to cancer immunotherapy. J. Leukoc. Biol. 2017, 102, 727-740. [CrossRef]

132. Bar, N.; Costa, F.; Das, R.; Duffy, A.; Samur, M.; McCachren, S.; Gettinger, S.N.; Neparidze, N.; Parker, T.L.; Bailur, J.K.; et al. Differential effects of PD-L1 versus PD-1 blockade on myeloid inflammation in human cancer. JCI Insight 2020, 5. [CrossRef]

133. Cassetta, L.; Pollard, J.W. Targeting macrophages: Therapeutic approaches in cancer. Nat. Rev. Drug Discov. 2018, 17, 887-904. [CrossRef]

134. Cannarile, M.A.; Weisser, M.; Jacob, W.; Jegg, A.M.; Ries, C.H.; Rüttinger, D. Colony-stimulating factor 1 receptor (CSF1R) inhibitors in cancer therapy. J. Immunother. Cancer 2017, 5, 53. [CrossRef]

135. Wiehagen, K.R.; Girgis, N.M.; Yamada, D.H.; Smith, A.A.; Chan, S.R.; Grewal, I.S.; Quigley, M.; Verona, R.I. Combination of CD40 agonism and CSF-1R blockade reconditions tumor-associated macrophages and drives potent antitumor immunity. Cancer Immunol. Res. 2017, 5, 1109-1121. [CrossRef]

136. Weber, A.N.R.; Bittner, Z.; Liu, X.; Dang, T.M.; Radsak, M.P.; Brunner, C. Bruton's tyrosine kinase: An emerging key player in innate immunity. Front. Immunol. 2017, 8, 1454. [CrossRef]

137. Yang, H.; Zhang, Q.; Xu, M.; Wang, L.; Chen, X.; Feng, Y.; Li, Y.; Zhang, X.; Cui, W.; Jia, X. CCL2-CCR2 axis recruits tumor associated macrophages to induce immune evasion through PD-1 signaling in esophageal carcinogenesis. Mol. Cancer 2020, 19, 41. [CrossRef]

138. Wang, W.; Marinis, J.M.; Beal, A.M.; Savadkar, S.; Wu, Y.; Khan, M.; Taunk, P.S.; Wu, N.; Su, W.; Wu, J.; et al. RIP1 Kinase Drives Macrophage-Mediated Adaptive Immune Tolerance in Pancreatic Cancer. Cancer Cell 2018, 34, 757-774. [CrossRef] 